\title{
BANGUNAN TAHAN GEMPA BERBASIS STANDAR NASIONAL INDONESIA
}

\author{
Prof. Suwandojo Siddiq
}

\begin{abstract}
Abstrak
When strong earthquake occurs, (Magnitude is larger than 6,0 SR), usually followed by earthquake damages, such as multi story buildings and non engineered structures (public houses), and big number of victims, in the area close to epicenter. If the location of hypocenter is under bottom of the sea, its depth is less than $30 \mathrm{~km}$ (shallow earthquake), the magnitude $M$ is not less than 7.0, and the type of earthquake is thrust or dip-slip, the earthquake may be followed by tsunami (tsunami is Japanese words, means harbor sea-waves). Great tsunami with run up more than 2.0 meters is able to destroy every thing on the beach and kill big number of human lives.

Earthquake shock will generate ground acceleration, and may cause building/housing damages and collapses. The damaged buildings are caused by weakness of building/house structures, such as: bad quality of buildingmaterials, unperfected structural configuration, utilization of unsuitable building materials and/or building structures, and the last but most important is not implemented SNI-guidance regarding aseismic (anti-seismic) structures properly.

This paper will discuss the weakness of public houses (Non Engineered Structures) and Multi story Structures (Engineered Structures), and the role or the function of SNI in improving quality and safety of buildings against earthquake motion.
\end{abstract}

Keywords: weakness of building/house structures, mutu bahan bangunan, quality of building-materials, SNI, Non Enginered Structures (NES), Enginered Structures (ES).

\section{PENDAHULUAN}

\subsection{Latar Belakang}

Sebagian besar kepulauan Indonesia, merupakan kawasan rawan terhadap bahaya bencana gempa bumi. Hanya wilayah Kalimantan Barat dan Kalimantan Tengah saja yang dapat dikatakan bebas terhadap bahaya gempa. Sepanjang Pulau Sumatera bagian barat, Pulau Jawa bagian selatan, NTB dan NTT, merupakan kawasan gempa sedang sampai gempa kuat, atau merupakan kawasan yang berhadapan langsung dengan subduction di sepanjang Lautan Hindia yang membentang dari barat (Aceh) sampai ketimur (NTT). Sulawesi Utara dan Tengah, Kepulauan Maluku dan Pulau Irian Barat sepanjang sisi utara, merupakan kawasan rawan gempa kuat juga. Gempa terakhir (akhir tahun 2004), terjadi Nabire, Alor dan Nanggroe Aceh, banyak menimbulkan kerugian materi dan korban jiwa. Kasus gempa Aceh Desember 2004, menimbulkan korban lebih dari 105 ribu jiwa, belum termasuk yang cedera dan hilang. Ringkasnya, gempa sedang sampai kuat, sering merusak atau menghancur- kan banyak bangunan dan menimbulkan banyak korban jiwa.

Sering terjadi, bahwa kejadian gempa menjadi bencana, karena menimbulkan banyak kerusakan harta benda dan korban jiwa. Korban jiwa terjadi akibat tertimpa bangunan yang roboh mendadak, karena tidak kuat menahan beban dinamik gempa. Bangunan yang sudah dibuat tahan gempa, tidak akan rusak atau roboh walaupun terjadi gempa. Bangunan yang tidak roboh, tidak menimbulkan bencana, sehingga bencana dapat dicegah atau dikurangi.

\subsection{Kegempaan Dunia dan Di Indonesia}

Di seluruh muka bumi, terdapat 8 (delapan) lempeng tektonik utama. Lempeng Pasifik, dikenal sebagai lempeng yang teraktif. Wilayah Indonesia terletak di antara 4 lempeng aktif, yaitu Lempeng Pasifik, Eurasia, Australia dan lempeng Pilipina. Dimensi, posisi dan arah gerak semua lempeng tektonik dunia, ditunjukkan pada Gambar 1 berikut. 


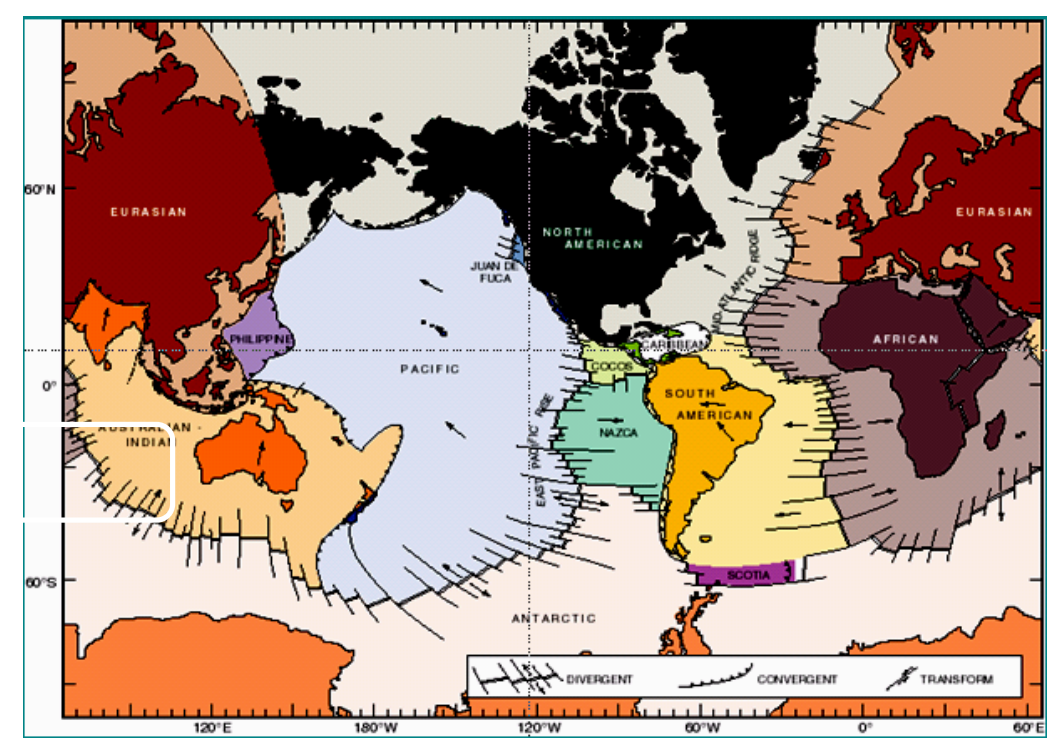

Gambar 1 Lempeng Tektonik dunia, yaitu Eropa-Asia (Eurasian), Australia, Pasifik, Nazca, Amerika Selatan, Amerika Utara, Atlantik, Antartika, Afrika, Cocos, dan Pilipina. Indonesia terletak pada pertemuan antara lempeng Australia (yang bergerak ke arah utara), lempeng Pasifik (yang bergerak ke arah Utara-Barat) dan lempeng Eurasia. Sehingga peristiwa gempa sering terjadi (gempa kuat rata-rata terjadi 3 kali setiap 2 tahun di Indonesia).

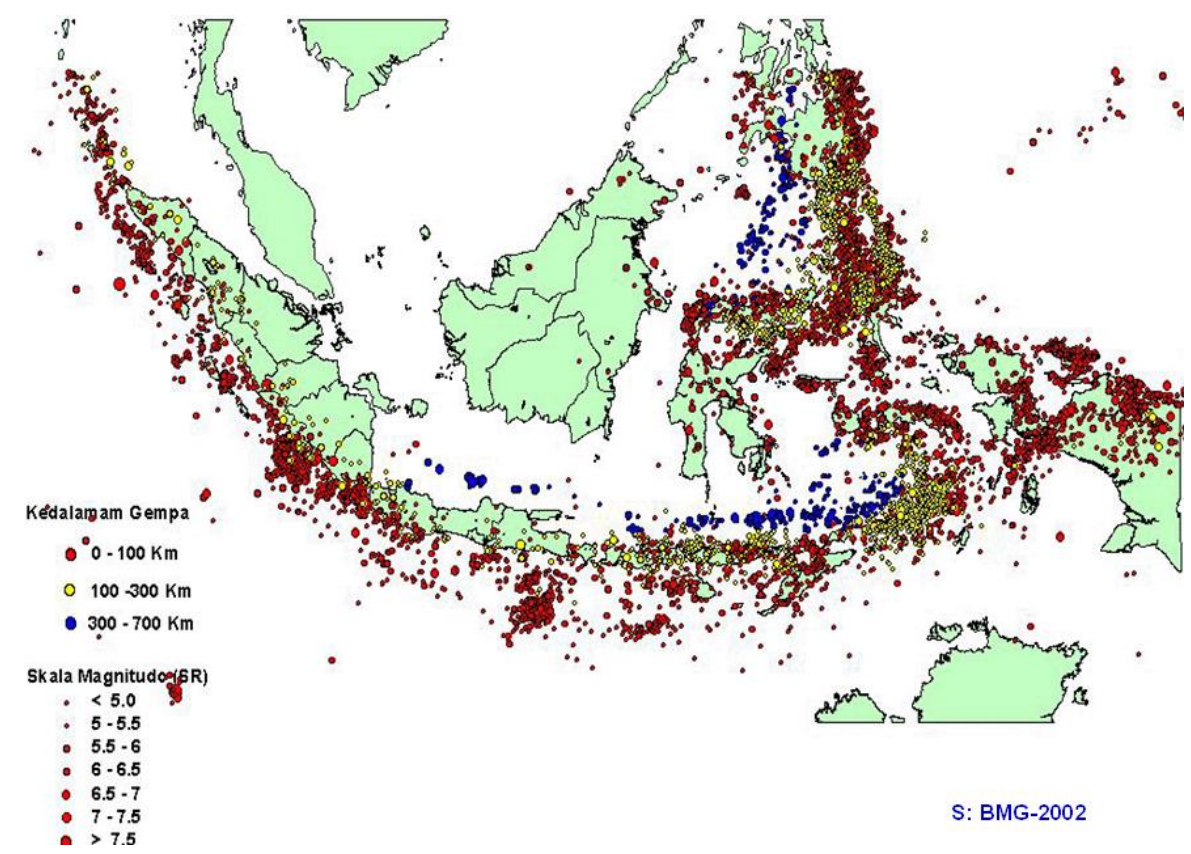

Gambar 2 Titik-titik lokasi epicentrum, magnitud dan kedalaman gempa yang terjadi di Indonesia selama 10 tahun (1991 s/d 2001).

Sumber BMG 2002

Setiap tahun, di wilayah Indonesia rata-rata terjadi gempa kuat yang merusak, sebanyak satu sampai dua kali (atau $3 x$ per 2 tahun). Maka upaya untuk mencegah terjadinya kerusakan bangunan dan bencana adalah: 
1) membuat tahan gempa terhadap bangunan baru yang akan dibangun;

2) memperkuat bangunan yang lemah (yang sudah ada) agar kuat terhadap gaya gempa yang akan terjadi, repairing, strengthening and retrofitting.

3) memperbaiki dan memperkuat bangunan telah rusak (ringan $\mathrm{s} / \mathrm{d}$ sedang) akibat gempa sebelumnya, agar kekuatan dan kekakuannya dapat dikembalikan seperti kondisi semula, atau lebih kuat/kaku.

Untuk mendesain bangunan baru atau meperbaiki, maka beban gempa desain ditentukan berdasarkan zoning gempa Indonesia yang baru: (SNI gempa 2002) berikut:

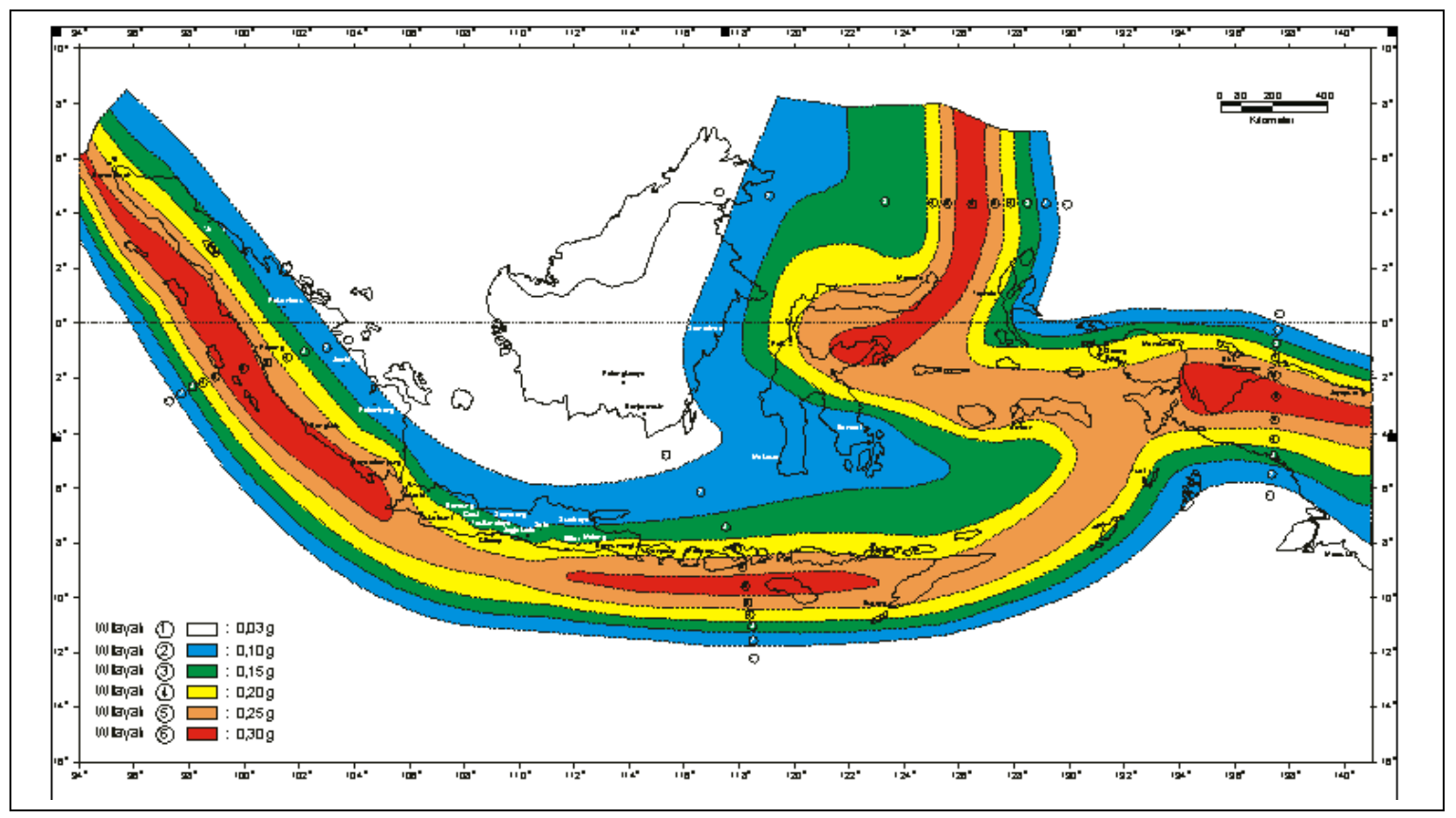

Gambar 3 Peta wilayah gempa Indonesia dengan percepatan puncak batuan-dasar, dengan periode ulang 500 tahun.

Zone-6, merah, wilayah gempa terkuat. Zone-1, warna putih, wilayah bebas gempa. Jakarta dan Yogya, misalnya, terletak diantara Z-4 (kuning) dan Z-3 (hijau), maka digunakan Z-4 200 gals.

\section{JENIS KERUSAKAN BANGUNAN DAN PENYEBABNYA}

\subsection{Sebab-Sebab Kerusakan Bangunan}

\subsubsection{Tingkat Kerusakan Struktur Bangunan dan Faktor Penyebabnya}

Dari hasil pengamatan lapangan pada kerusakan bangunan akibat gempa, (di Indonesia juga di Kobe Jepang 1995), selama lebih dari 20 tahun (sejak gempa Tasikmalaya, Garut 1979), maka dapat disimpulkan sebagai berikut [Kepust 5\&6]:

a. Tingkat kerusakan bangunan akibat gempa tergantung dari [Kepust 14, 15 \& 16]:

- Kekuatan gempa,

- Intensitas gempa,
- Durasi atau lamanya gempa berlangsung,

- Kondisi tanah dan struktur geologi tanah,

- Banyaknya frekwensi getaran tanah,

- Konfigurasi struktur bangunan,

- Kontinuitas kekakuan struktur dan distribusi massa tingkat,

- Kekuatan dan daktilitas struktur bangunan,

- Mutu bahan bangunan,

- Mutu pengerjaan konstruksi bangunan.

b. Faktor penyebab kerusakan struktur bangunan:

- Kesalahan konfigurasi sistem struktur, (tidak mengikuti kaidah struktur bangunan tahan gempa, seperti 
keteraturan, kontinuitas, kesimetrisan pada seluruh bagian bangunan),

- Adanya perlemahan (lubang bukaan yang besar) pada dinding (pasangan) struktural,

- Tidak meratanya distribusi kekakuan (arah vertikal dan horizontal),

- Tidak meratanya distribusi beban (massa tingkat), dan besarnya lengan eksentrisitas (jarak pusat massa CM dan pusat kekakuan CR ),

- Kurangnya kekakuan, kekuatan dan daktilitas struktur,

- Struktur lapisan tanah, daya dukung tanah fondasi dan daya dukung kompnen struktur fondasi.

c. Jumlah kurban (manusia) tergantung dari:

- Kepadatan penduduk di wilayah yang terkena gempa,

- Waktu (jam) terjadinya gempa (contoh Gempa Kobe, 1995, terjadi pada jam 6:15 pagi, banyak warga menggunakan peralatan dapur gas untuk memasak, kebakaran rumah kayu dalam jumlah besar tidak dapat dihindari, kurban meninggal di wilayah perumahan ini lebih dari 5000 jiwa). [Kepust 5]

- Kesiapan warga (penduduk) untuk mengantisipasi terjadinya gempa setiap waktu.

\subsubsection{Bahan Bangunan dan Kecocokan Sistem Struktur terhadap Beban Seismik}

Tidak semua bahan bangunan dan sistem struktur bangunan yang digunakan oleh masyarakat, memiliki ketahanan yang baik terhadap beban lateral dinamik akibat gempa. Dalam tabel berikut secara ringkas dikelompokkan tingkat kecocokannya sistem struktur dengan ketahanannya terhadap beban seismik.

Tabel 1 Jenis Bahan, Sistem Struktur dan Daya Dukung terhadap Gempa [Kepust 1,3,5 \& 6]

\begin{tabular}{|c|c|c|c|c|c|c|}
\hline \multirow[t]{2}{*}{ No } & \multirow[t]{2}{*}{$\begin{array}{l}\text { Jenis Bahan dan Sistem } \\
\text { Struktur Bangunan }\end{array}$} & \multicolumn{4}{|c|}{$\begin{array}{c}\text { TINGKAT KECOCOKAN } \\
\text { TERHADAP BEBAN LATERAL } \\
\text { GEMPA }\end{array}$} & \multirow[t]{2}{*}{ CATATAN } \\
\hline & & $\begin{array}{c}\text { Sangat } \\
\text { Baik }\end{array}$ & Baik & $\begin{array}{l}\text { Kurang } \\
\text { Baik }\end{array}$ & Jelek & \\
\hline 01 & $\begin{array}{l}\text { Dinding pasangan } \\
\text { bata/batako polos }\end{array}$ & & & & $\kappa$ & $\begin{array}{l}\text { Bobotnya besar, regas, } \\
\text { (brittle), tidak daktail }\end{array}$ \\
\hline 02 & $\begin{array}{l}\text { Pasangan bata dgn perkuatan } \\
\text { (confined) }\end{array}$ & & $\kappa$ & $\kappa$ & & \multirow{4}{*}{$\begin{array}{l}\text { Bobot sedang, daya } \\
\text { dukung sedang, } \\
\text { daktilitas sedang. }\end{array}$} \\
\hline 03 & $\begin{array}{l}\text { Pasangan conblok dengan } \\
\text { perkuatan (confined) }\end{array}$ & & $\kappa$ & $\kappa$ & & \\
\hline 04 & $\begin{array}{l}\text { Pasangan hollow conblock } \\
\text { bertulang (R/M) }\end{array}$ & & $\kappa$ & & & \\
\hline 05 & $\begin{array}{l}\text { Rangka kayu + pasangan } \\
\text { bata (dengan jangkar) }\end{array}$ & & $\kappa$ & & & \\
\hline 06 & $\begin{array}{l}\text { Struktur rangka kayu + } \\
\text { bracing }(X \text {-brace) }\end{array}$ & $\kappa$ & $\kappa$ & & & \multirow{4}{*}{$\begin{array}{l}\text { Berat sendiri minimum, } \\
\text { daya dukung sedang } \\
\text { s/d tinggi, kekakuan } \\
\text { dan daktilitas tinggi. }\end{array}$} \\
\hline 07 & $\begin{array}{l}\text { Struktur rangka beton } \\
\text { bertulang, } \mathrm{R} / \mathrm{C} \& \text { SRC }\end{array}$ & $\kappa$ & & & & \\
\hline 08 & $\begin{array}{l}\text { Struktur rangka baja ringan + } \\
\text { bracing }\end{array}$ & $\kappa$ & $\kappa$ & & & \\
\hline 09 & Struktur rangka baja kaku & $\kappa$ & & & & \\
\hline
\end{tabular}

Catatan: Polos = tanpa perkuatan; $\mathrm{R} / \mathrm{M}=$ Reinforced Masonry (B3-B, pasangan blok beton berongga dengan tulangan).

\subsection{Kegagalan Struktur Bangunan dan Teknik Perbaikan dan Perkuatan}

Dari pengamatan dan studi lapangan selama lebih dari 20 tahun terhadap kerusakan bangunan akibat gempa yang terjadi di berbagai tempat di Indonesia, menunjukkan bahwa penyebab kerusakan tersebut erat hubungannya dengan:

a. rendahnya mutu bahan, seperti kayu lapuk, kuat tekan beton rendah, keropos, 
b. rendahnya mutu konstruksi (pengerjaan), seperti beton tanpa kompaksi,

c. tidak efektif atau kurang benarnya sistem dan konfigurasi struktur,

d. tidak efektif atau kurang benarnya penyelesaian detail sambungan antar komponen,

e. kondisi tanah, jenis dan lapisan tanah di lapangan, f. kekuatan dan lamanya getaran gempa berlangsung.

Jenis kerusakan bangunan akibat gempa di Indonesia, seperti tercantum dalam Tabel 1, dijelaskan secara faktual di dalam foto-foto berikut:

\subsubsection{Bangunan Rumah (NES) dengan Struktur Rangka Kayu (Tradisional)}
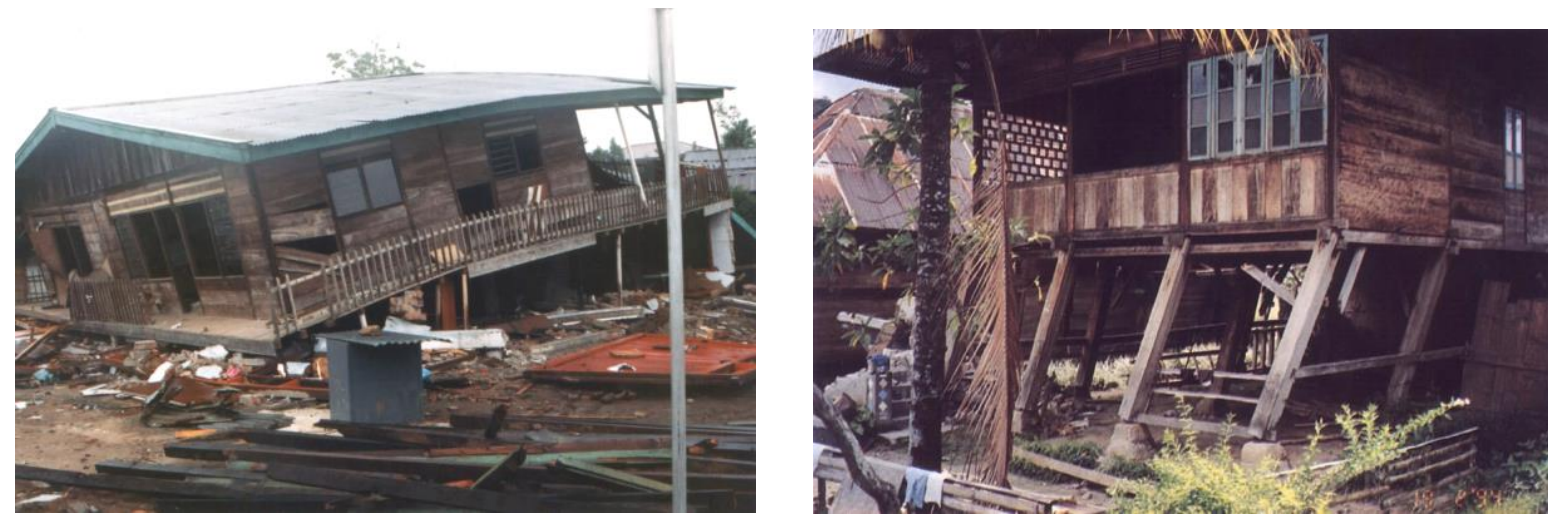

Gambar 4 Struktur Rangka Kayu pada Bangunan Penduduk (Tradisional) Sumatera

Kelemahan struktur rangka bangunan seperti terlihat di Gambar 4 adalah:

a. massa (beban-tingkat) besar terpusat di lantai atas, dan

b. stuktur rangka bawah lemah dan tidak kaku, soft story. Ikatan antara kaki kolom dengan fondasi umpak tidak ada.

c. sistem sambungan kolom dan balok (sistem takikan) tidak kaku dan lemah, akibatnya bangunan mudah tumbang bila terkena beban datar (lateral). Gempa Liwa 16-21994.

Saran Perbaikan Konstruksi (Rumah Kayu):

a. mengkakukan kolom-kolom di tingkat bawah dengan memasang diagonal bracing (batang pengaku-silang),

b. memperbaiki teknik sambungan kolom bawah dengan kolom atas,

c. menggunakan kayu yang tidak mudah lapuk untuk komponen struktur vertikal (berat jenis kayu $\geq 0,55$ ), d. memperbaiki hubungan kaki kolom dengan fondasi,

e. mengikat kaki kaki kolom dua arah (seperti tie-beam)

f. memperbaiki hubungan kaki kolom dengan fondasi umpak, dengan memasang pelat baja+baut sebagai jangkar pengikat.

\subsubsection{Struktur Dinding Pasangan Bata Polos}

Umumnya, bangunan rumah penduduk, menggunakan dinding struktur pasangan bata polos, tanpa perkuatan atau tanpa sistem penahan beban gempa. Foto berikut menunjukkan runtuhnya dinding pasangan bata polos, diikuti jatuhnya rangka atap secara mendadak, yang langsung menimpa penghuninya yang tidak sempat menyelamatkan diri. 
Bangunan (NES), Struktur Pasangan Bata Polos, Runtuh Akibat Gempa

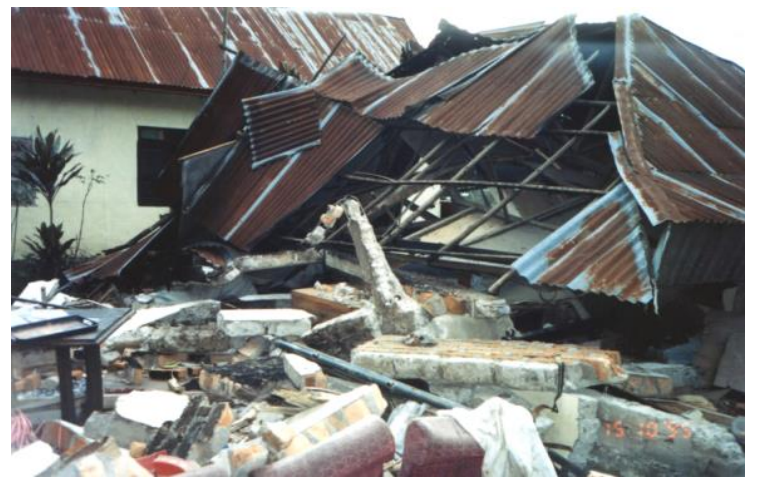

Gambar 5a Struktur pasangan bata polos, bobot matinya besar, kekuatan dan daktilitasnya terhadap beban lateral (gempa) sangat rendah, sehingga mudah runtuh total pada gempa Kerinci 7-10-1995.

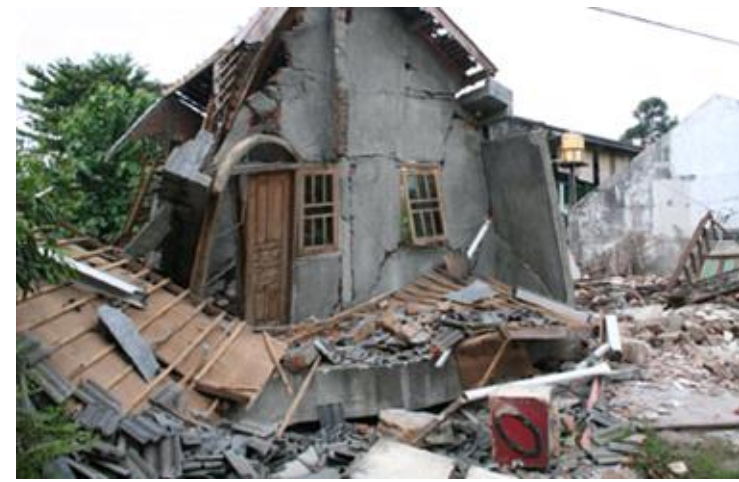

Gambar 5b Rusak berat (runtuh total) bangunan rumah yang struktur vertikalnya terbuat dari dinding pasangan bata polos, tanpa komponen perkuatan. Akibat Gempa Yogya 27-5-2006.

Runtuh Bangunan Penduduk NES Pasangan Bata Polos, Akibat Gempa Yogya

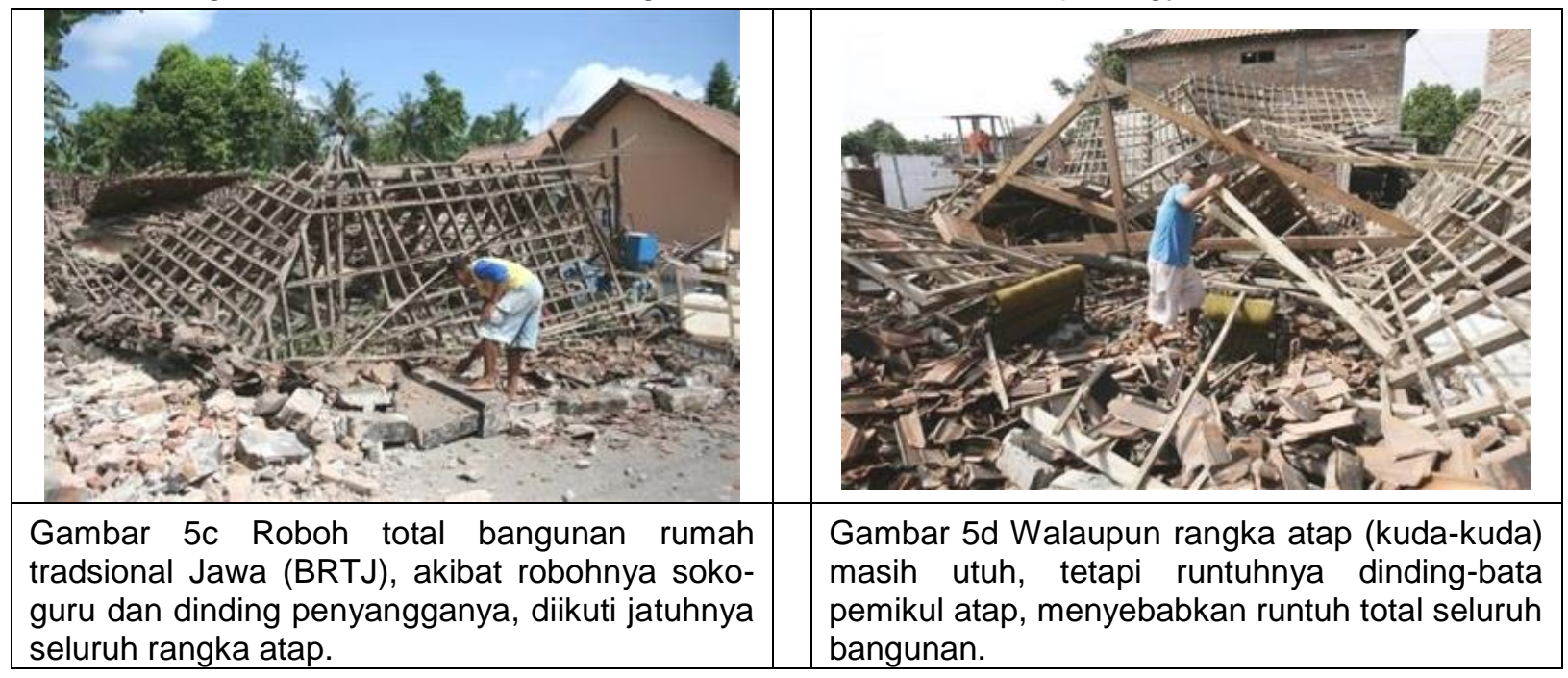

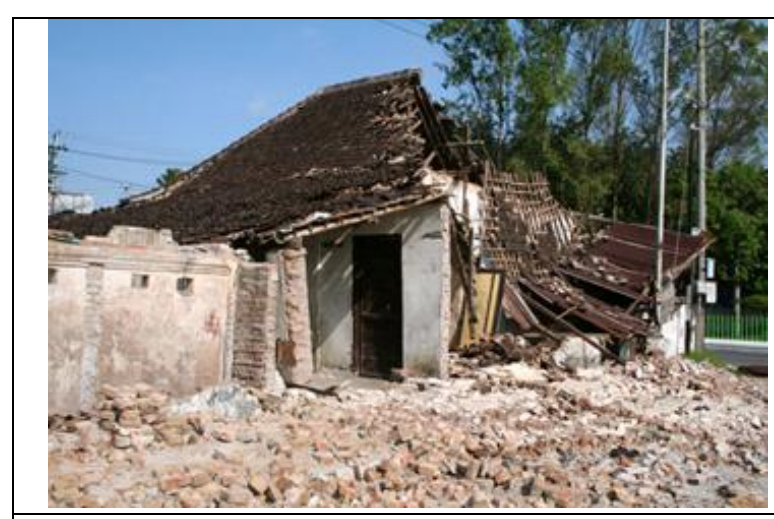

Gambar 5e Dinding bata polos roboh, diikuti jatuhnya rangka atap. Bata reruntuhan dinding berserakan akibat rendahnya mutu adukan, (latar depan). Gempa Yogya, Kab. Bantul.

Saran Perbaikan Struktur:

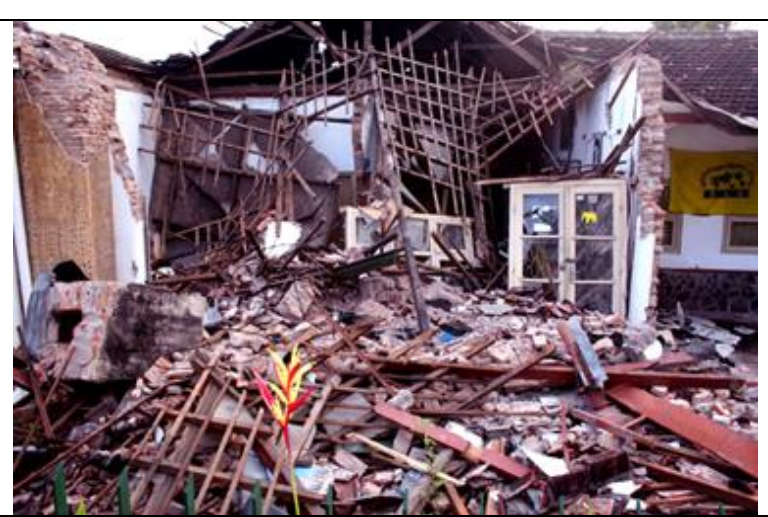

Gambar $5 f$ Dinding pasangan bata polos (P/M) berfungsi sebagai bearing wall, mendukung kuda-kuda atap, runtuh total, diikuti jatuhnya rangka atap. Kota Yogya.

Untuk mencegah runtuhnya sistem struktur ini, disarankan menggunakan penguat sistem 
rangka beton bertulang atau rangka kayu, sehingga dinding pasangan yang dikelilingi oleh balok dan kolom beton atau kayu dapat berfungsi sebagai confined-masonry dan shearwall. Kuat terhadap gempa.

\subsubsection{Bangunan NES dengan Struktur Kombinasi Rangka Kayu \& Pasangan Bata}

Rangka kayu, berfungsi sebagai pengekang dinding (confinement), bila dilengkapi baja pengikat antara dinding kepada kerangka kayu akan mampu meningkatkan dinding sebagai struktur tahan gempa.

Saran Perbaikan Konstruksi:

a. perkuat sambungan/ikatan antara balok dan kolom kayu dengan paku PB-100 - $120 \mathrm{~mm}$,

b. pasang batang angker (baja penampang 6-8 $\mathrm{mm}$ ) di sisi dalam rangka kayu, yang berfungsi sebagai pengikat dinding pasangan ke kolom dan balok.

c. dinding bata dipasang lagi menggunakan adukan 1PC : 4 - 5 Pasir.
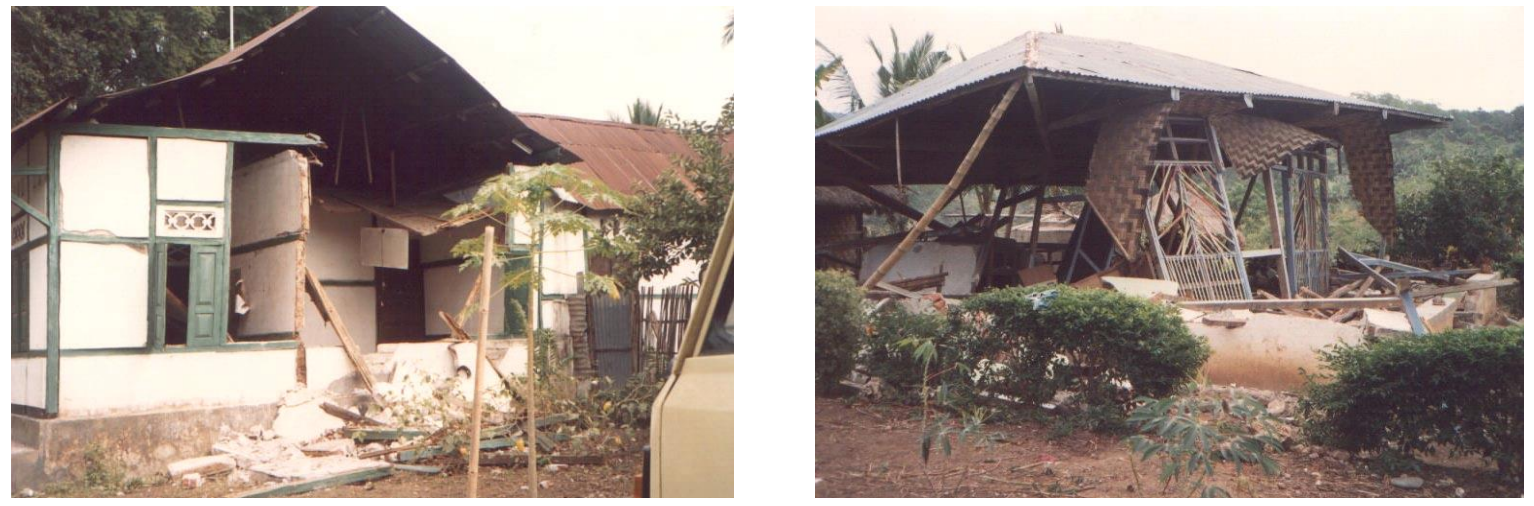

Gambar 6 Struktur rangka kayu yang dikombinasikan dengan pasangan bata sebagai pengisi (infill-wall), tetapi tidak dilengkapi besi jangkar yang mengikat sisi-sisi dinding terhadap kolom \& balok kayu. Bobot mati pasangan yang besar menghasilkan gaya inersia lateral (face load) yang besar, menyebabkan pasangan bata runtuh total. Gempa Flores 12-12-1992.

\subsubsection{Bangunan NES, dengan Struktur Rang- ka Beton Bertulang Dikombinasikan de- ngan Dinding Pasangan Bata}

Jenis bangunan ini banyak mengalami kerusakan berat sampai runtuh total. Hal ini disebabkan oleh faktor berikut:

a. dinding bata bobotnya besar (berat) tetapi bersifat getas (britle). Dinding pasangan polos, tidak memiliki ketahanan terhadap gaya lateral geser, jadi mudah patah atau roboh

b. mutu bahan dan mutu pengerjaan jelek, tidak memiliki kekuatan yang cukup untuk menahan beban gravitasi dan lateral gempa, yang terjadi pada struktur, sehingga struktur mudah rusak dan/atau runtuh. Mutu pengerjaan yang jelek, juga akan menghasilkan mutu konstruksi yang buruk dan lemah.

Struktur ini masih baru selesai dibangun, masih belum beratap, tetapi runtuh disebabkan oleh

a. mutu bahan beton yang sangat rendah (foto kiri),

b. detail tulangan yang tidak memenuhi syarat "kesatuan komponen", yaitu ujung tulangan balok tidak terjangkar cukup dalam ke kolom, demikian juga ujung tulangan kolom tidak terjangkar cukup panjang ke balok,(foto kanan), lihat Gambar 5d.

c. join balok-kolom tidak dilengkapi dengan sengkang penahan geser dan pengekang inti join (confining steel). 


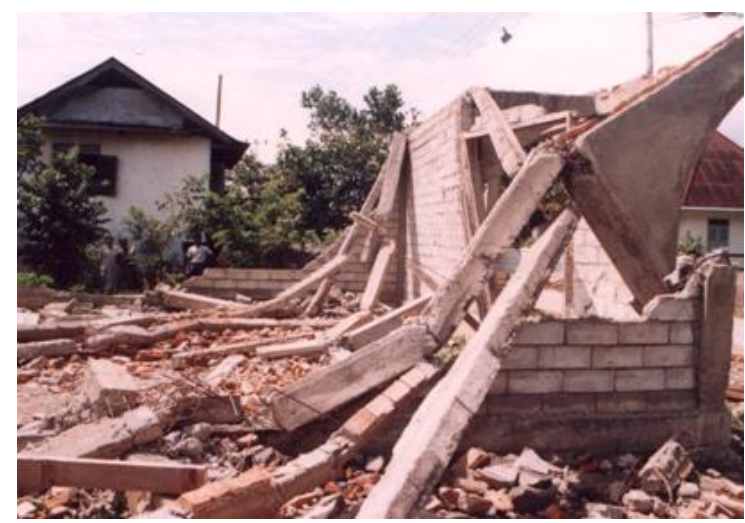

Gambar 7a Gempa Kerinci, Sumatera 7-101995, Struktur rangka beton bertulang yang dikombinasikan dengan dinding pasangan bata pengisi (infill-wall).

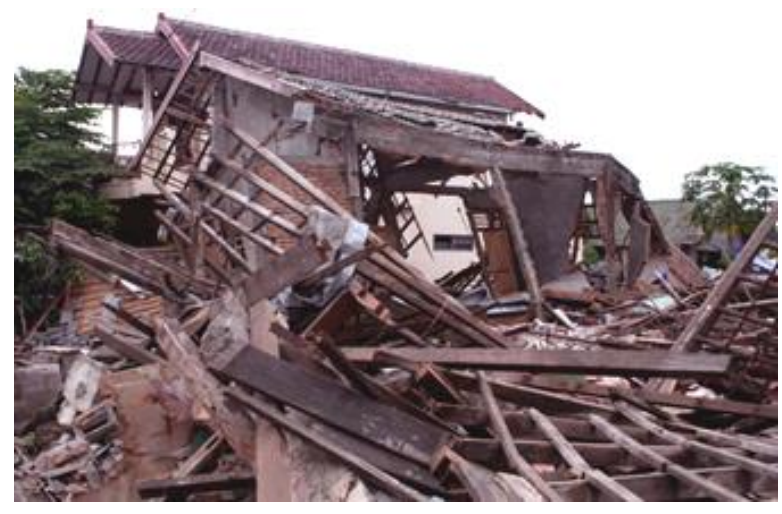

Gambar 7b Runtuh struktur rangka beton (BTRS), akibat kelemahan pada joint (BCJ, Beam Column Joints), diikuti dgn jatuhnya seluruh rangka atap.

Contoh Kesalahan Detail Baja Tulangan pada Join Balok-Kolom:

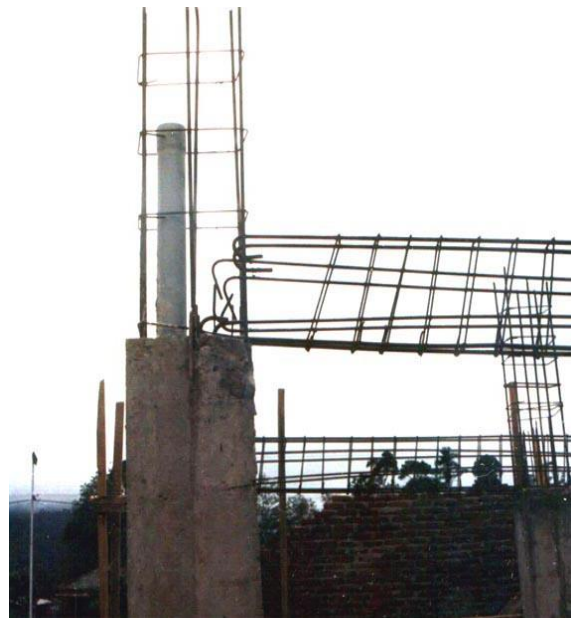

Gambar 8a Contoh detail bajatulangan struktur rangka beton yang salah, yang menyebabkan keruntuhan bangunan pada Gambar 5e. Ujung batang tulangan balok tidak terjangkar ke dalam kolom atau balok lainnya. Gempa Liwa Palembang16-2-1994.

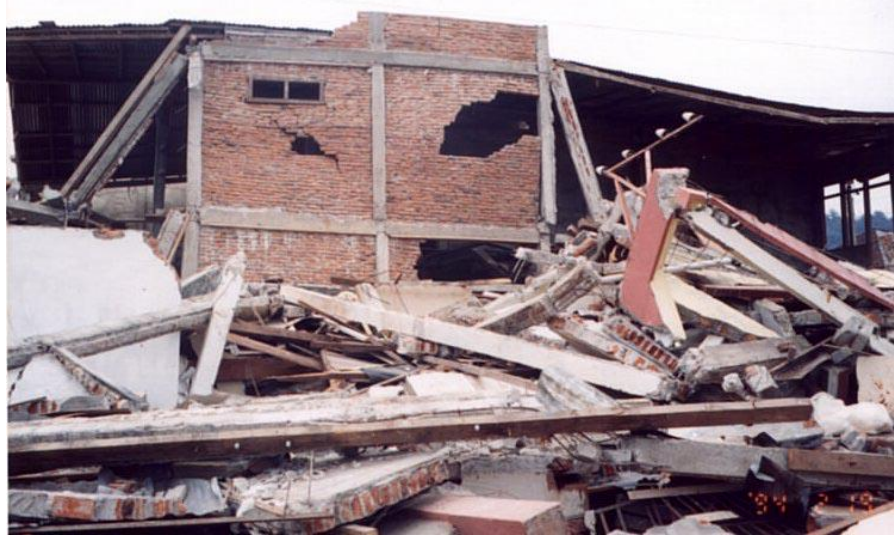

Gambar 8b Struktur rangka beton bertulang yg dikombinasikan dengan dinding pasangan bata. Foto kiri dan kanan, bangunan runtuh disebabkan oleh: (1) dinding bata tidak diperkuat dg tulangan penahan beban tegak lurus bidang (face load), (2) penyelesaian detail join komponen beton yang tidak sesuai dengan ketentuan bangunan tahan gempa (lihat keterangan Gambar 5d), (3) mutu pengerjaan yang rendah. Gempa Liwa 16-2-1994.

\section{Saran perbaikan:}

Untuk mencegah terjadinya keruntuhan seperti ini, maka harus dilakukan:

a memperbaiki mutu beton dan mutu pengerjaan. Campuran bahan untuk $1 \mathrm{~m}^{3}$ beton misalnya $300 \mathrm{~kg}$ PC:800 kg Pasir:1000 kg Kerikil dan 200 Liter air, dapat digunakan untuk struktur bangunan sederhana.

b penyelesaian detail tualangan harus mengikuti ketentuan struktur tahan c gempa SNI Beton tahun 2002, yaitu ujung tulangan suatu komponen rangka harus terjangkar cukup kuat ke dalam komponen lain yang tersambung satu sama lain.

d memasang beberapa tulangan sengkang (penahan geser dan pengekang inti join) pada join balok kolom. 


\subsection{Kasus Gempa Yogya (Gempa Sedang- Kuat, 27-05-2006)}

\subsubsection{Bahan dan Tipe Struktur yang Banyak Digunakan}

a Bangunan penduduk (atau NES, bangunan Tanpa Rekayasa Struktur, TRS), berfungsi sebagai rumah tinggal atau bangunan fasilitas umum, banyak menggunakan bahan bata sebagai dinding pasangan stuktural (pemikul beban vertikal dari atap atau lantaitingkat + atap), rangka-kayu + papan atau gedek, rangka-kayu + dinding pasangan $1 / 2-$ bata, atau rangka beton bertulang + dinding pasangan setengah-bata (tebal dinding 12 $15 \mathrm{~cm}$ ).

b Pada bangunan besar dan/atau bertingkat banyak (2-6 tingkat, atau Engineered Structures, ES), biasa digunakan struktur rangka beton bertulang yang dikombinasikan dengan dinding pasangan bata sebagai dinding pengisi antar kolom (non structural infill wall).

C Struktur yang dirancang dengan mengikuti ketentuan SNI gempa dan SNI struktur beton tidak mengalami kerusakan yang berarti, struktur utamanya tidak mengalami kerusakan struktural, seperti kasus gedung kampus terpadu UII di JI. Kaliurang. Sedangkan bangunan yang tidak mengikuti ketentuan SNI, mengalami kerusakan berat, seperti kasus gedung BPKP, FTIE dan ISI.

\subsubsection{Definisai Bangunan "TRS" (atau NES) dan "DRS" (atau ES).}

a. Bangunan Tanpa Rekayasa Struktur "TRS" (NES, Non Engineered Structures)

"Bangunan Penduduk" adalah bangunan yang dibangun oleh penduduk dengan metoda konstruksi sederhana/tradisional, tanpa sentuhan rekayasa struktur dan/atau teknologi konstruksi dan analisa struktur rasional tahan gempa. pada:

Kelemahan Struktur TRS, biasanya terletak

- Mutu bahan bangunan rendah, seperti kayu lunak, tua/lapuk; beton kuat tekan rendah;

- Lemahnya sistem sambungan antar batangkomponen, seperti sambungan takikan/gigi (tounge \& grouve) atau cara tradisional Jawa,

- Rendahnya mutu adukan/mortar, yaitu menggunakan semen merah dan pasir, kadang-kadang kapur, (tanpa semen),

- salah konfigurasi dinding struktural, seperti besarnya lobang bukaan (luas bukaan pintu dan jendela, melebihi batas maksimum 50\% dari luas bidang dinding),

b. Bangunan dengan Rekayasa Struktur", DRS (atau ES, Engineered Structures)

"Bangunan DRS", yaitu bangunan yang dirancang dan dibangun oleh ahli bangunan atau ahli struktur dan konstruksi, berdasarkan kaidah statika rasional dan rekayasa struktur yang benar, rasional dan efektif

Kelemahan yang terjadi pada Struktur Rangka Beton Bertulang terhadap gempa, antara lain:

- Kesalahan konfigurasi struktur, dan kesalahan konsep desain struktur (misal soft column effect, short column effect, torsion effect dan kelemahan terhadap geser),

- Rendahnya mutu beton, kuat tekan beton rendah, beton keropos dsb.

- Kesalahan proses konstruksi atau rendahnya mutu pengerjaan.

\subsubsection{Kelemahan dan Kerusakan Bangunan}

a. Bangunan TRS Struktur-Kayu

Kerusakan bangunan (khususnya perumahan) tradisional jawa, dengan struktur rangka kayu, umumnya disebabkan oleh faktor berikut:

- akibat aging/umur kayu (kayu sudah tua/lapuk atau mutu kayu rendah, misal $\mathrm{BJ} \leq 0,40$ ),

- akibat lemahnya sistem sambungan antar komponen rangka kayu, (sambungan tradisional dengan gigi takik atau purusan), tanpa alat sambung (fastener),

- salah campuran pada adukan untuk dinding pasangan bata (dinding pengisi antara kolom); penggunaan semenmerah (serbuk bata merah) + pasir, akan menghasilkan aduk yang sangat rendah kekuatannya. Semen merah adalah bukan bahan pengikat agrigat pasir. Bila digunakan kapur sebagai perekat (bukan semen), juga akan menghasilkan mortar yang rendah mutunya (kuat tekan sekitar $5-10 \mathrm{~kg} / \mathrm{cm}^{2}$ ). Karena itu dinding pemikul atap banyak yang tumbang (roboh) akibat beban lateral (face-loads) yang ditimbulkan oleh gaya inersia gempa. Dindingnya roboh, tetapinya batanya masih tetap utuh, artinya aduknya lebih lemah dari batanya, dan akibat faktor kelangsingan dan beban eksentris.

Contoh rusaknya bangunan tanpa rekayasa struktur, BTRS (NES), dan keterangan sebab- 


\section{Bangunan NES, Bangunan penduduk, tradisional Jawa, struktur Rangka-kayu}

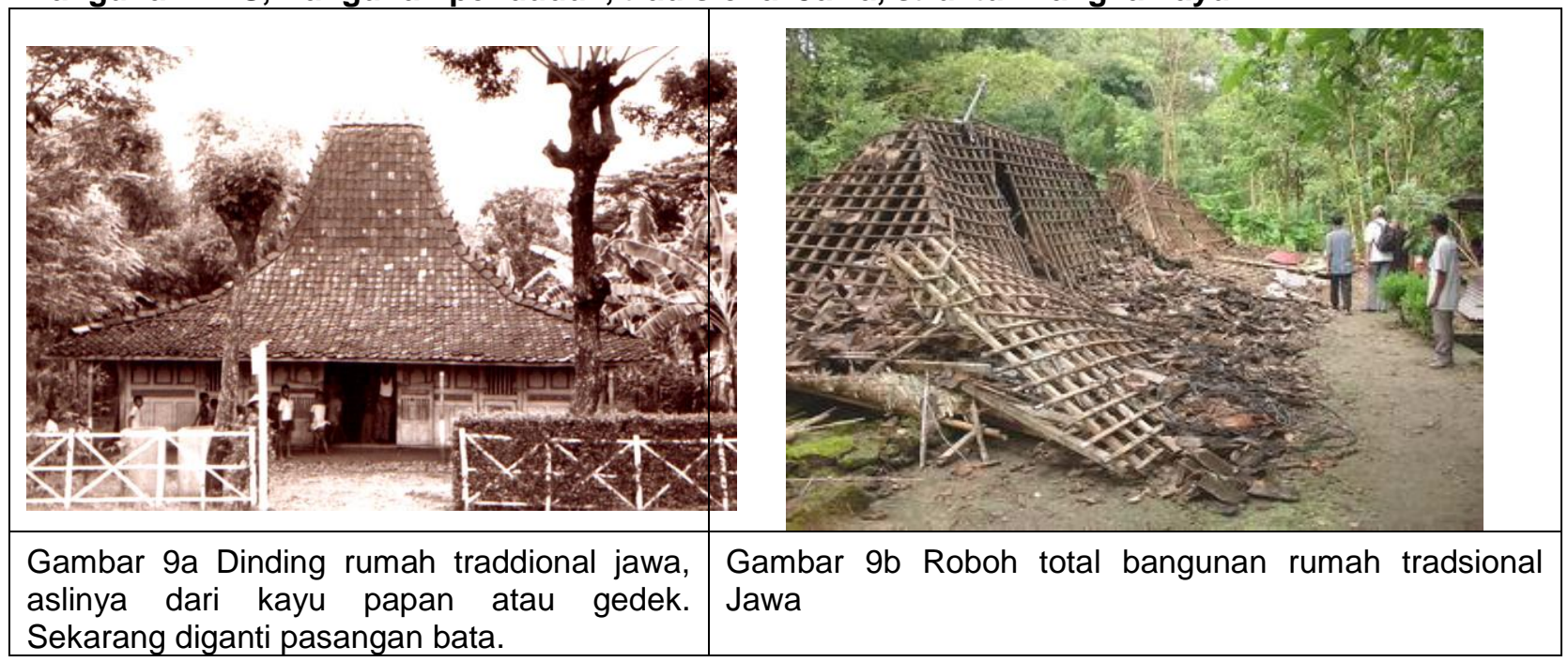

Detail Sambungan-tradisional Jawa, komponen rangka kayu kolom dan balok sunduk bandang, sunduk kili, sistem sambungan catokan.

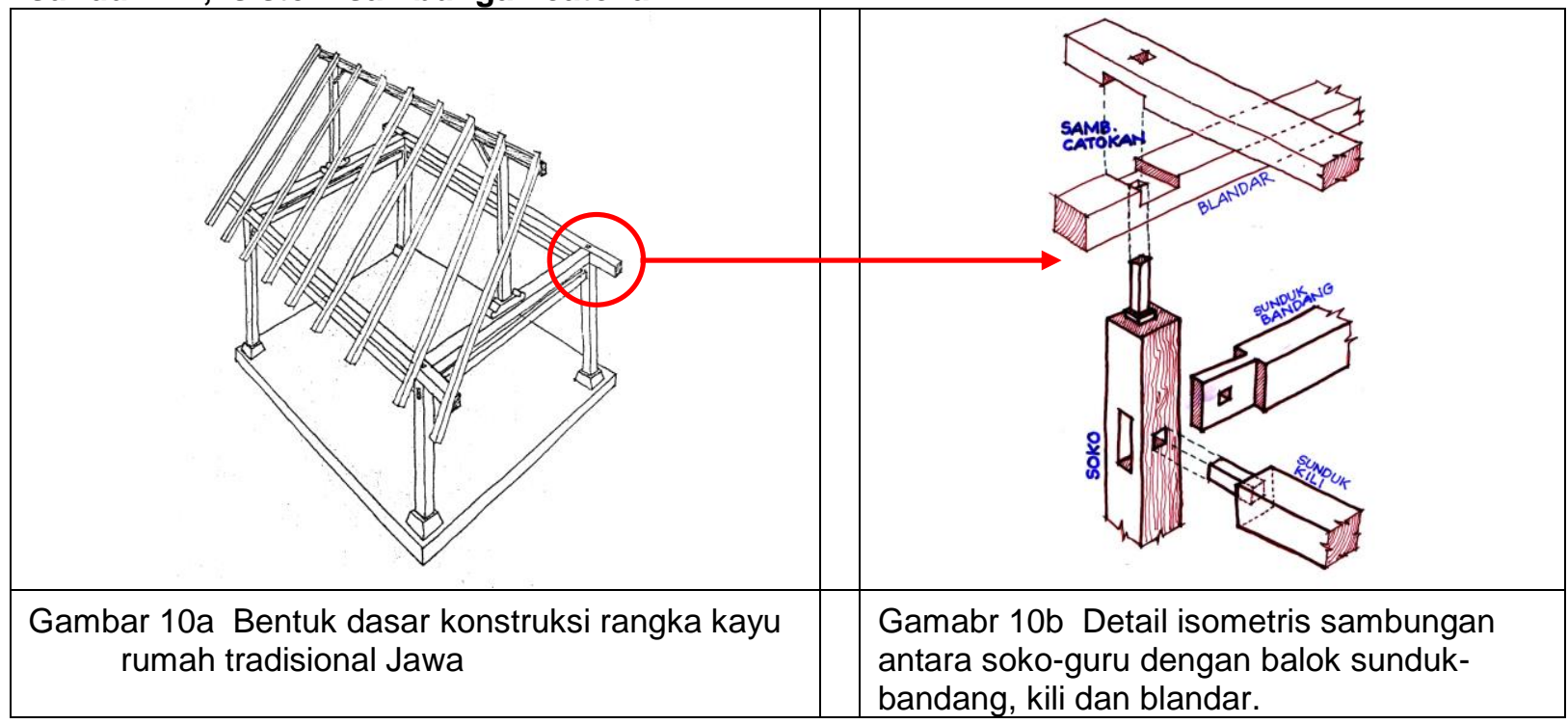

b. Bangunan Tanpa Rekayasa Struktur, "TRS", Struktur Rangka Kayu Tradisional KratonJawa,

Konsep Struktur Rangka Tradisional Jawa

Bentuk Joglo, pada dasarnya memiliki empat Tiang Utama (Soko-guru). Tetapi disesuaikan dengan fungsinya, maka untuk memperluas denah bangunan, maka joglo berkembang menjadi 4 Soko guru ditambah 12 tiang disekelilingnya seperti "Joglo Jompongan", "Joglo Sinom" (dengan 12 tiang di emperannya), joglo "Mangkurat" dan Joglo "Tajug Mangkurat" dan "Tajug Jeblokan" yang memiliki 4-soko guru ditambah 28 soko-guru lapis luar.

Walaupun bangunan tradisional Jawa mempunyai sejumlah variasi, tetapi sistem sambungan antara soko-guru dengan balok pengikat keliling (blandar, sunduk bandang dan sunduk-kill), yang berfungsi sebagai pengaku struktur di bagian atas. Sedangkang kaki-kolom (soko-guru), tertumpu bebas di atas fondasiumpak, yang ujung bawahnya diberi lidah (sunduk) sepanjang $5-7 \mathrm{~cm}$, masuk ke dalam sisi atas umpak. Karena itu kaki kolom bersifat sendi (tidak kaku, mudah berputar) dan sedangkan ujung kolom-atas (diharapkan) bersifat "agak-kaku". Lihat Gambar 11a sampai 11c. Sambungan ini tidak mungkin mencapai 
kaku-sempurna. Karena stabilitas empat sokoguru, hanya dihasilkan dari sunduk-bandang dan sunduk-kili ditambah dua-balok-blandar dengan sambungan "catokan". Semuanya hanya ditahan dan/atau disatukan oleh "sunduk", (ujung-atas soko-guru yang ditakik) yang berpenampang sekitar 50 × $50 \mathrm{~mm}$ (atau $5 \times 5 \mathrm{~cm}$ ).

Detail Konstruksi Struktur Rangka Kayu Tradisional Jawa (Kraton)

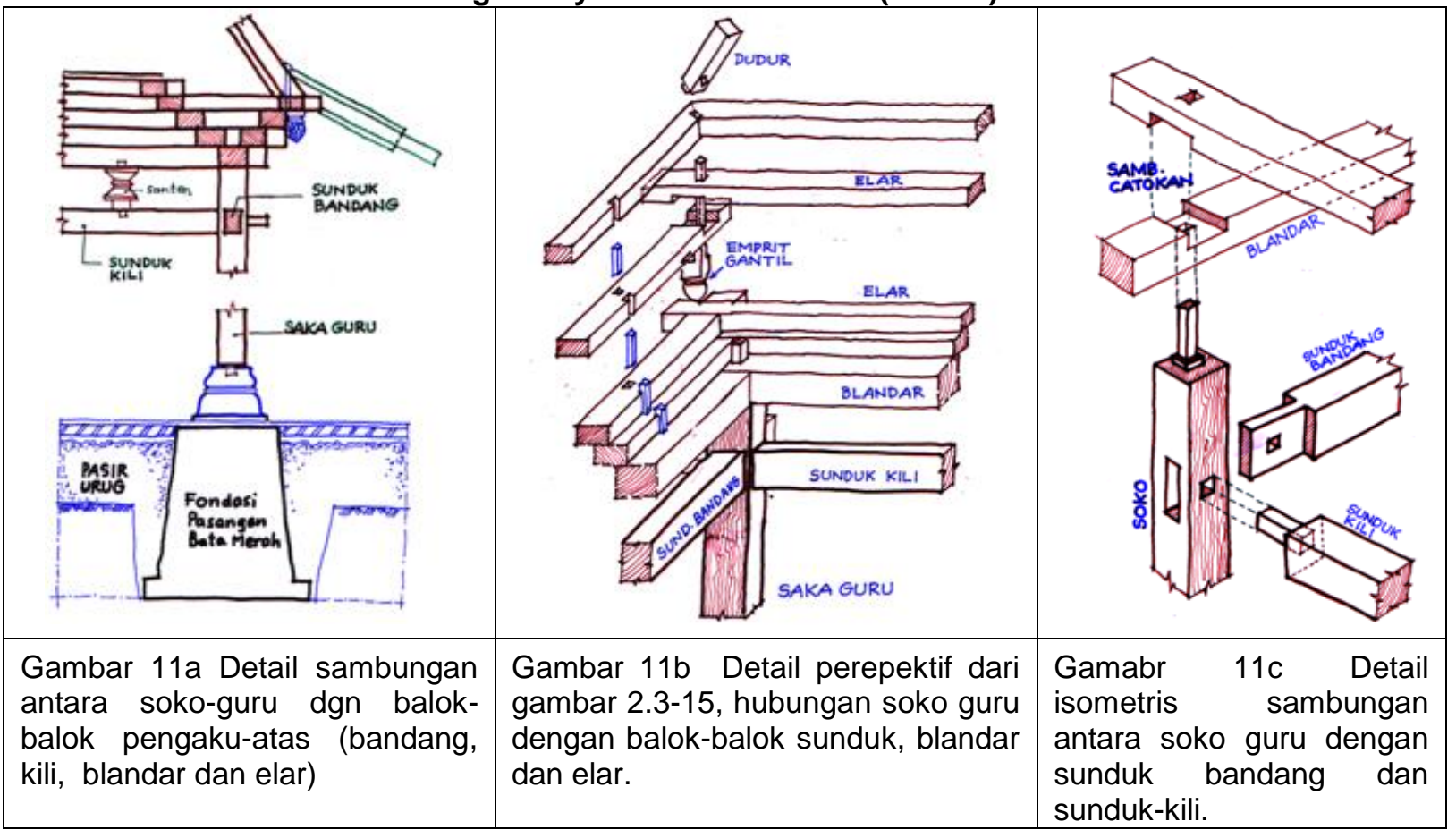

Bangunan Tradisional Jawa, Joglo Keraton, Struktur Rangka-Kayu Tradisional. Roboh Akibat Gaya Lateral-Gempa Yogya 27-5-2006.

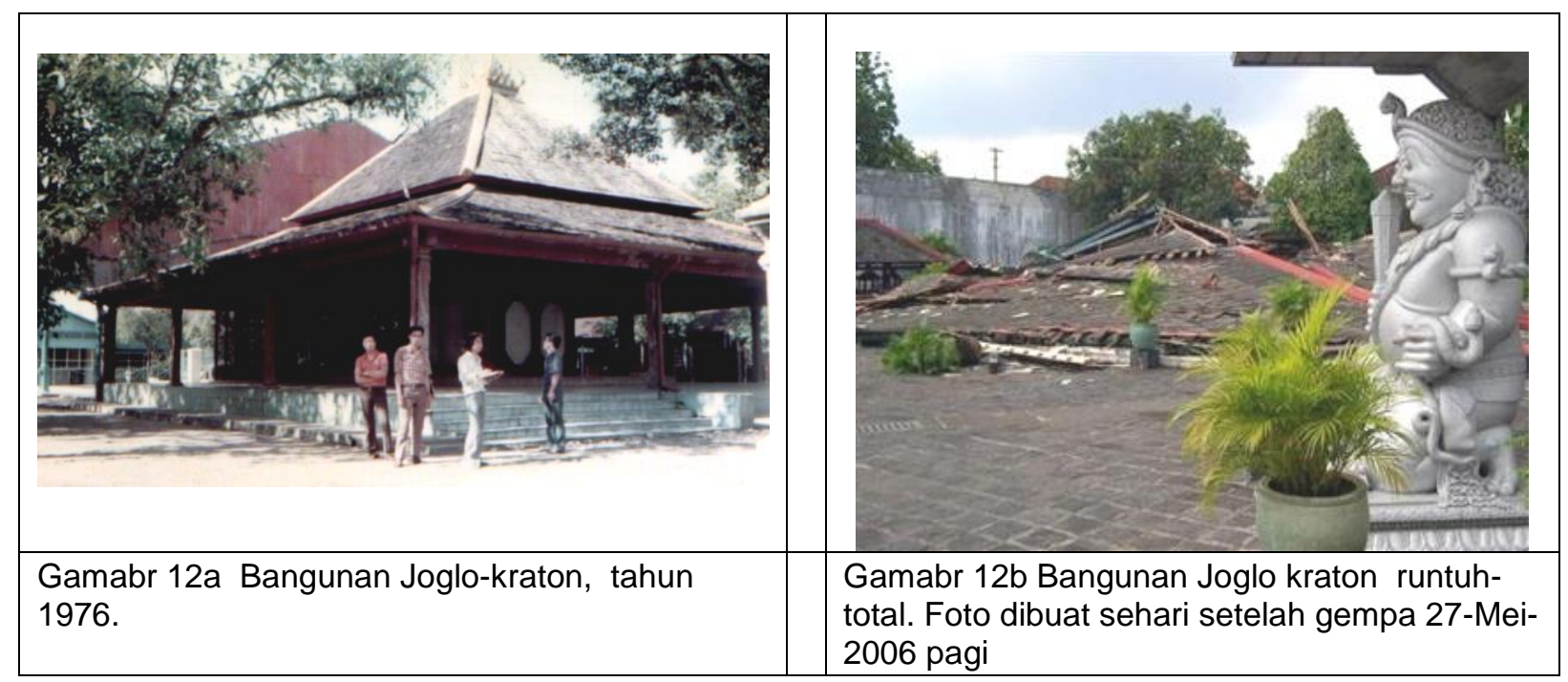

Detail Sambungan dengan metoda "Purusan dan

\section{Catokan"}

Gambar 11a memperlihatkan hubungan kaki kolom-kayu (soko-guru) dengan fondasi umpak, tanpa alat sambung (fastenner pelat baja angkur ke dalam fondasi). Kaki kolom mudah terlepas dari tumpuanya, diikuti miringnya bangunan joglo.

Bagian ujung atas kolom, disambung dengan balok sunduk kili dan sunduk bandang (menggunakan sambungan takikan dan lobang alur + pen, lihat Gambar 11c) yang befungsi 
sebagai pengaku struktur rangka. Dan paling ujung atas terdapat 2 balok blandar dalam arah saling tegak lurus, yang berfungsi sebagai alas "balok elar", juga berfungsi sebagai hiasan langit-langit yang berjumlah ganjil, 3, 5, 7 atau 9 . Lihat gambar 11a, 11b dan 11c.

Sistem sambungan ini sangat lemah dan tidak kaku. Mudah patah (runtuh) bila terkena gaya lateral gempa, lihat Gambar $12 a$ dan $12 b$ Joglo Kraton.

c. Bangunan dengan Rekayasa Struktur BDRS, Engineered Structures

Jenis kerusakan struktur bangunan dengan rekayasa Struktur, B-DRS, dapat dikelompokkan sebagai berikut:

- Rusak akibat kelemahan struktur di tingkat terbawah, "soft colum effect", misal: kasus runtuhnya gedung STIE dan BPKP Yogya,

- Lemahnya sambungan-balok-kolom, BeamColumn-Joint weakness, misal kasus rusak dan runtuhnya gedung STIE Yogya,

- Kolom rusak geser akibat "kolom pendek", "Short column effect, misal kasus rusak dan runtuhnya gedung Institut Seni Indonesia, ISI,

- Kurangnya baja sengkang penahan geser pada kolom dan joint, misal kasus rusak dan runtuhnya gedung STIE dan ISI,

- Akibat Torsi, misal: kasus rusak dan runtuhnya gedung BPKP dan ISI.

Ketentuan SNI Struktur Beton:

- Seharusnya, kolom harus lebih kuat dari balok. Kaidah struktur tahan gempa: "STRONG COLUMN WEAK BEAM". Tetapi Joint harus tetap elastis ketika kolom mendekti leleh.

- Bila balok sudah rusak (leleh, terjadi sendi plastis), seharusnya bangunan tidak boleh runtuh dan kerusakan struktur masih bisa diperbaiki.

- Tetapi bila kolom rusak lebih dahulu, atau join-join sudah rusak, maka bangunan akan runtuh total, dan tidak akan bisa diperbaiki.
Pada gambar-gambar berikut, akan ditunjukkan dan dijelaskan contoh kerusakan strukur rangka beton bertulang (Enginered Structures, ES) dan penyebabnya.

\section{- Gedung STIE Yogya (Gambar 13a dan 13b)}

Bangunan STIE, 4 tingkat, menggunakan struktur rangka beton bertulang (open rigid frame structure). Dimensi penampang kolom yang relatif langsing (sekitar $300 \times 300 \mathrm{~mm}$ ), spasi kolom sekitar 4,0 meter.

Beban tekan aksial akibat beban gravitasi (DL+LL) terhadap kolom terbawah $(4 \times 4 \times 4 \times 1)$ sekitar 65 ton. Jika mutu beton $f^{\prime} c=20 \mathrm{~s} / \mathrm{d} 25$ $\mathrm{MPa}$., maka nilai rasio $\phi_{0}$ yang terjadi $=$ $(650000 / 300 / 300) /(20 \mathrm{~s} / \mathrm{d} \quad 25)=0,36 \mathrm{~s} / \mathrm{d} \quad 0,29$. Hasil research di Laboratorium Struktur Puslitbang Permukiman oleh penulis makalah ini (1993) menunjukkan bahwa syarat kolom daktail $\phi_{0} \leq 0,20$. Jadi Struktur Frame R/C STIE kurang stabil dan tidak daktail. Tetapi karena di tingkat atas dipasang banyak dinding dan tingkat terbawah terbuka tanpa dinding, maka kelemahan struktur menjadi bertambah besar akibat kondisi "SOFT STORY EFFECT". Akibat yang logis adalah struktur rangka runtuh total akibat torsi dan geser.

\section{- Gedung BPKP (Gambar 14a dan 14b)}

Bangunan gedung BPKP, 2 tingkat, struktur rangka kaku beton bertulang. Di tingkat bawah terbuka (bukaan jendela kaca). Di tingkat atas lebih kaku banyak dinding. Akibatnya soft story. Sisi timur (kiri) struktur bangunan lebih kaku, sehingga bangunan sisi barat yang tingkat bawahnya terbuka (soft story) mengalami deformasi puntir (torsi). Jadi bangunan runtuh akibat kombinasi soft story dan torsi. 


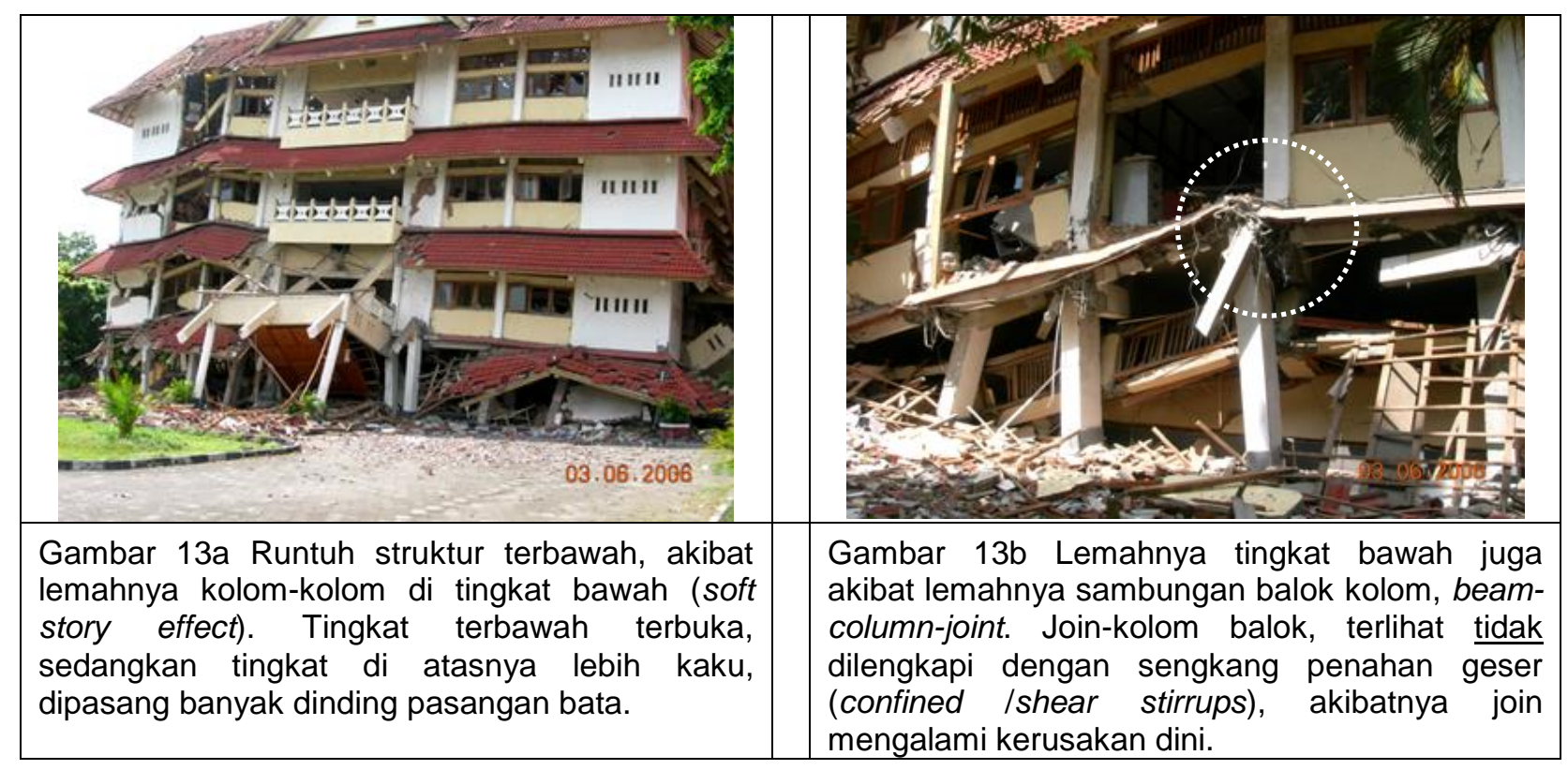

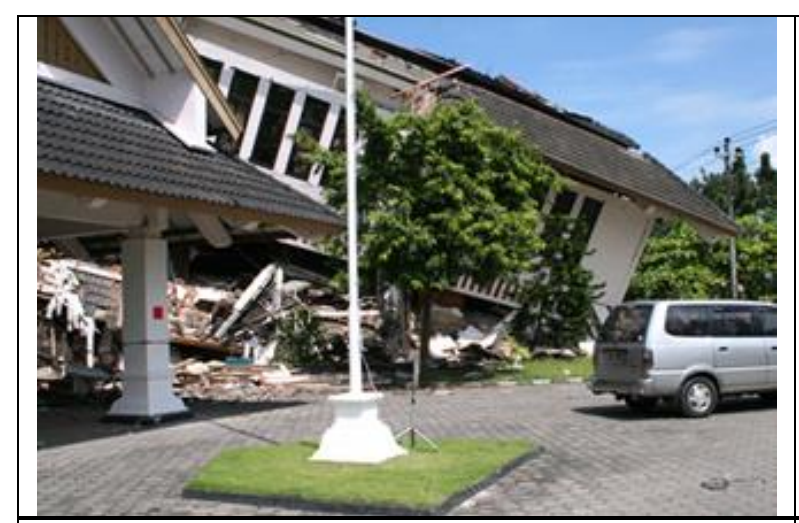

Gambar 14a Bagian barat (kanan) gedung runtuh akibat torsi dan soft column effect.

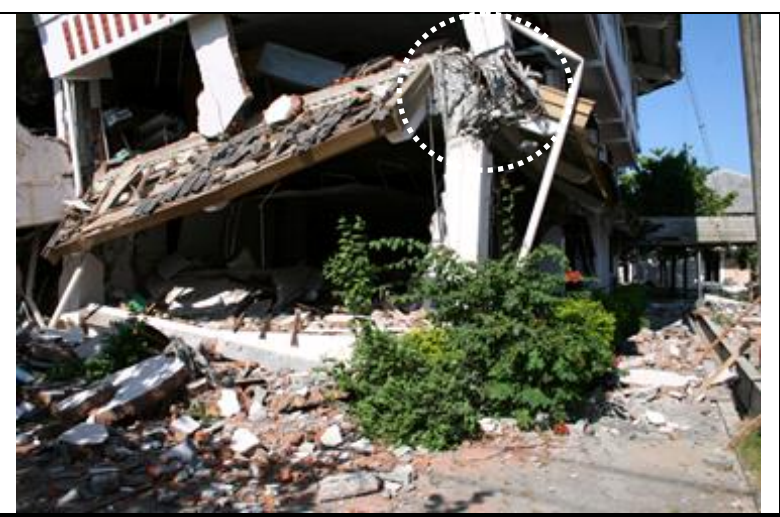

Gambar 14b Rusak geser pada BCJ (beamcolumn-joint), akibat kurangnya sengkang penahan geser.

\section{- Gedung Institut Seni Indonesia (Gambar 15 a-c)}

Bangunan ISI, 3 tingkat, struktur rangka kaku terbuka dari bahan beton bertulang ( $R / C$-open rigid frame). Spasi kolom arah longitudinal sekitar 6,0 meter, di arah melintang (bentang tepi kiri - bentang tengah - bentang tepi kanan) $=6$ $m-3 m-6 m$.

Memperhatikan tipe kerusakan kolom-kolom yang telah terjadi, menunjukkan bahwa kolom rusak akibat kombinasi compressived block failure, torsi, geser dan soft column effect.

Kelemahan kolom-kolom dan join yang rusak geser disebabkan oleh terlalu kecilnya diameter sengkang $(8 \mathrm{~mm})$, dan kurang rapatnya spasi antar sengkang (spasi yang ada $s \geq 200 \mathrm{~mm}$ ), sedangkan ketentuan "SNI-Beton Struktur-2002", menetapkan bahwa, untuk struktur tahan gempa, spasi maksimum sengkang kolom $\mathrm{s} \leq 100 \mathrm{~mm}$.
Akibatnya, ujung-kolom dan join di tingkat bawah mengalami rusak-berat, akibat geser. Lihat Gambar 15a, 15b dan 15c.

Kerusakan kolom struktur dapat dianalisa sebagai berikut.

- Dimensi penampang kolom $\approx 450 \times 450 \mathrm{~mm}$. Dalam arah melintang gedung terdapat 4 kolom, spasi $\approx 6 m-3 m-6 m$. Dalam arah memanjang terdapat 6 deret kolom, spasi 6,0 meter. Beban tekan maksimum pada kolom terbawah akibat (DL+LL) di saat terjadi P-wave gempa $\approx 1,5 \times\{(6+3) / 2 \times 6\} \times$ $3 \times 1$ ton $=121,5$ ton. Bila mutu beton (diasumsikan) $\quad f^{\prime} c=25 \quad M P a ., \quad$ maka $f^{\prime} c, a=1215000 /(450 \times 450)=6,0 \mathrm{MPa}$. $\phi \mathrm{o}=6 / 25=0,24$ ternyata $>0,20$ batas maks. struktur daktail.

- Beban geser lateral per-kolom sekitar $\approx$ $\{0,15(15 \times 30 \times 3) \times 1$ ton $)\} /(4 \times 6)=8,438$ ton . 
Tegangan geser $\mathrm{v}, \mathrm{a}=84380 /(450 \times 450)=$ $0,417 \mathrm{MPa}$. Ini harus ditahan oleh sengkang $\phi=8 \mathrm{~mm}$, spasi $>200 \mathrm{~mm}$. Gaya tarik pada batang sengkang (akibat gaya geser di kolom $)=(0,417 \times 450 \times 200) / 2=18765 \mathrm{~N}$ $(18,765 \mathrm{kN})$ melebihi kekuatan sengkang $=$ $(\pi / 4 \times 82) 240=12058 \mathrm{~N} \quad(=12,06 \mathrm{kN})$. Putusnya sengkang diikuti rusaknya kolom, seperti ditunjukkan pada gbr 2.3-16.
- kerusakan tekan-aksial yang berlebihan, diikuti "meledak"-nya kolom ke arah lateral, sengkang terputus atau terlepas, lihat gambar 2.3-16, yang disebabkan oleh: rendahnya kuat-tekan beton, dan tidak kuatnya sengkang-pengekang.

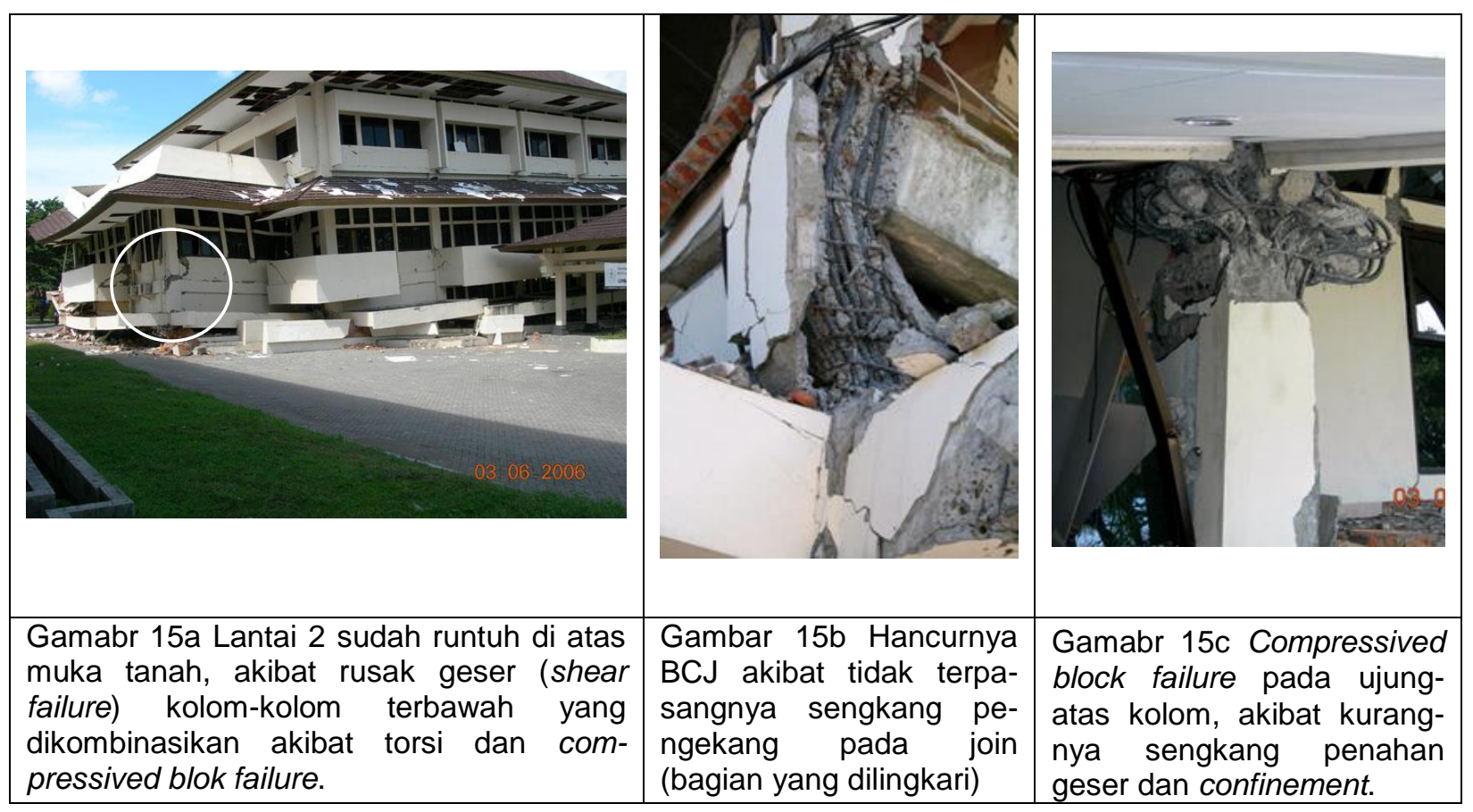

\section{SNI DAN BANGUNAN TAHAN GEMPA}

\subsection{Nama-nama SNI}

Nama-nama SNI yang digunakan untuk Perencanaan Struktur Bangunan Gedung dan Rumah Tahan Gempa adalah:

a Untuk Bahan Beton, digunakan SNI Rancangan Campuran Beton: "Tata Cara Pembuatan Rencana Campuran Beton Normal", SNI-03-2834-2000.

b Untuk menghitung dan menentukan "beban gempa desain", baik statik maupun dinamik, digunakan SNI Struktur Bangunan Tahan Gempa, oleh Badan Litbang Kimpraswil, Puslitbang Permukiman, 2002: "Tata Cara Ketahahan Gempa Untuk Bangunan Gedung", SNI-1726-2002.

c Untuk menghitung dan menentukan dimensi komponen struktur bangunan dari beton bertulang, baik kekuatan maupun daktilitas-

nya, digunakan SNI Struktur Beton Bertulang, oleh Balitbang PU, Puslitbang
Permukiman, 2002, Naskah Final RSNI: "Tata Cara Perencanaan Struktur Beton Untuk Bangunan Gedung”.

Catatan: Hingga saat ini, sudah 4 tahun diajukan ke BSN, nomor SNI-nya belum keluar.

SNI yang digunakan untuk perencanaan gedung bertingkat rendah, NES, atau gedung yang dibuat oleh penduduk tanpa perhitungan, tetapi tetap menganut kaidah tahan gempa:

- SNI Struktur Dinding Pasangan Bertulang B3-B, berjudul: "Tata Cara Perencanaan Dinding Struktural Pasangan Blok Beton Berongga Bertulang Untuk Bangunan Rumah dan Gedung", SNI-03-3430-1994.

\subsection{SNI dan Persyaratan Struktur Bangunan Tahan Gempa}

Ketentuan yang penting, yang mengatur persyaratan Struktur Beton Tahan Gempa, SNI Struktur Beton mengatur sebagai ditunjukkan secara ringkas dalam tabel dan gambar berikut. 


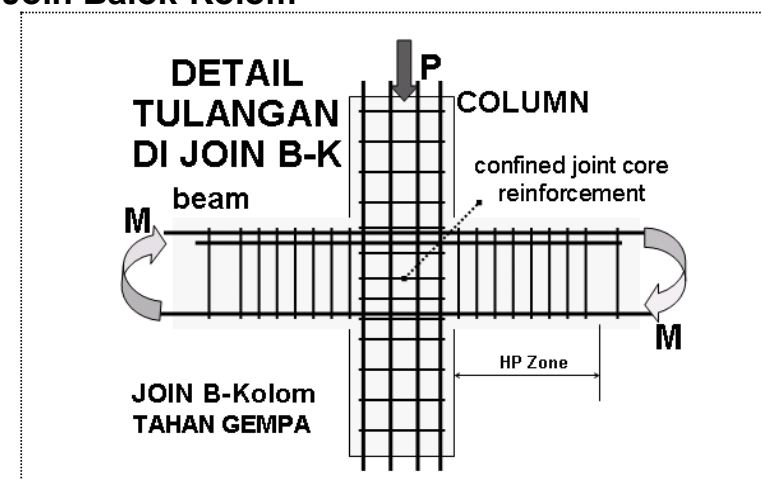

Ketentuan SNI pada Join interior

1) Ujung-ujung balok yang menyatu kepada join, dan berpotensi terbentuk sendi plastis,sepanjang $2 \times \mathrm{h}$ balok, harus dipasang sengkang penahan geser dengan spasi $\mathrm{s} \leq 100 \mathrm{~mm}$.

2) Pada inti join, harus dipasang sejumlah sengkang tertutup, yang berfungsi sebagai confinement dan penahan gaya geser.

3) Rasio luas tulangan tekan thd tarik, balok dekat join, As'/As $\geq 50 \%$.

\section{UPAYA PENYEBARLUASAN SNI STRUKTUR DAN KONSTRUKSI TAHAN GEMPA}

Upaya penyebarluasan SNI dan implimentasinya di wilayah Indonesia, memerlukan waktu yang cukup panjang, tenaga "penyuluh" yang ahli dan/atau terampil dan biaya yang memadai.

Sasaran utama "penyuluhan" SNI adalah kelompok yang bekaitan dengan kegiatankonstruksi, seperti: para pejabat teknis PU di daerah, konsultan, kontraktor, dosen dan mahasiswa di perguruan tinggi teknik.

\subsection{Upaya Penyebarluasan SNI oleh Badan Litbang PU}

Kendala yang sering dihadapi pada upaya penyebarluasan $\mathrm{SNI}$, antara lain:

(1) tidak tersedianya dan sulit didapatkannya buku-buku SNI dalam jumlah yang cukup di daerah-daerah,

(2) belum meluasnya upaya penyebarluasan SNI di daerah-daerah, terutama di luar Jawa.

(3) terbatasnya tenaga penyuluh atau ahli yang dapat diterjunkan ke daerah-daerah,

(4) terbatasnya dana yang mendukung kegiatan penyebarluasan SNI.

Setiap tahun Badan Litbang PU menyelenggarakan Kegiatan Sosialisasi NSPM (Norma, Standar, Pedoman dan Manual), khususnya yang menyangkut ke-PU-an, ke

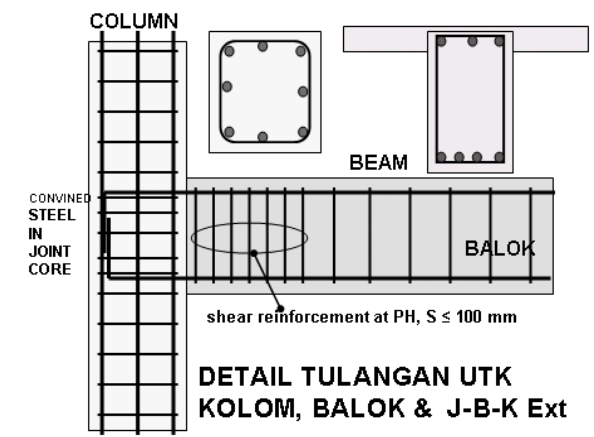

Ketentuan SNI pada Join eksterior

1) Ujung balok yang menyatu kepada join, dan berpotensi terbentuk sendi plastis,sepanjang 2xh balok, harus dipasang sengkang penahan geser dengan spasi $\mathrm{s} \leq 100 \mathrm{~mm}$.

2) Pada inti join, harus dipasang sejumlah sengkang tertutup, yang berfungsi sebagai confinement dan penahan gaya geser.

3) Rasio tulangan balok dekat join, As'/As $\geq 50 \%$.

daerah-daerah di seluruh Indonesia. Problem yang menonjol antara lain terbatasnya waktu penyuluhan dan waktu diskusi antara penyuluh dan peserta, sehingga pemahaman isi SNI secara lengkap tidak tercapai. Faktor kedua adalah tidak tersedianya buku-buku SNI yang disuluhkan dalam jumlah yang cukup. Peserta tidak memiliki buku SNI yang diperlukan untuk menunjang pekerjaannya.

\subsection{Penyebab Tidak Teraplikasikannya SNI dalam Bangunan}

Dari hasil studi lapangan di tempat kejadian gempa di Indonesia, rubuhnya banyak bangunan gedung dan rumah, bila dikaitkan dengan fungsi SNI bangunan tahan gempa, antara lain disebabkan oleh:

(1) Bangunan gedung dan rumah dibuat sebelum tahun 1980-an, yaitu sebelum terbit SNI Bangunan Tahan Gempa, atau bangunan dibangun sebelum ada pedoman, ketentuan dan SNI yang mengatur struktur bangunan tahan gempa. Misalnya rumahrumah yang sudah dibangun sebelum tahun 1950-an dan gedung-gedung bertingkat yang dibangun sebelum tahun 1970-an (misal gedung Fak Hukum, UII Yogya).

(2) Sudah terbit SNI, tetapi sosialisasinya atau bahan informasinya belum sampai atau tidak menjangkau ke daerah-daerah tertentu. 
Artinya pelaksana bangunan bekerja tanpa pengetahuan SN Tahan Gempa.

(3) Sosialisasi SNI sudah sampai (baik melalui seminar, kuliah atau workshop), tetapi tidak, pelaksana konstruksi (perencana dan/atau pelaksana/kontraktor) tidak melaksanakannya, dengan alasan: "melaksanakan SNI berarti mengurangi keuntungan".

(4) Sebagian masyarakat pengguna SNI, ingin menerapkan kaidah tahan gempa, tetapi kemampuan ekonomi tidak memungkinkannya, misalnya tidak mampu membayar biaya konstruksi dan biaya bahan bangunan yang bermutu-baik, (kasus masyarakat pedesaan golongan ekonomi lemah).

\subsection{Sasaran Penyebarluasan SNI}

Upaya sosialisasi atau penyebarluasan SNI, khususnya SNI Bangunan Tahan Gempa, akan lebih efektif bila diarahkan kepada:

(1) Perguruan Tinggi Teknik (Jurusan Sipil dan Arsitektur), baik kepada dosen struktur maupun mahasiswa tingkat akhir S1, S2 dan S3 Jurusan Struktur Bangunan.

(2) Para konsultan dan kontraktor bangunan gedung dan rumah,

(3) Para anggota Asosiasi profesional, seperti HAKI Himpunan Ahli Konstruksi Indonesia.

(4) Para pejabat PU daerah, khusunya pengawas dan pemberi izin bangunan.

\section{KESIMPULAN}

\subsection{Faktor Penyebab Kerusakan Struktur Bangunan}

- Rendahnya mutu bahan bangunan, seperti kayu lapuk, kuat tekan beton rendah,

- Rendahnya mutu pengerjan, seperti: penggunaan aduk yang salah, besarnya bukaan pada dinding pasangan bata, sistem sambungan tradisional yang lemah, mengecor beton tanpa pemadatan,

- Penggunaan bahan struktur yang tidak tepat, seperti pasangan dinding polos (tanpa penguat dan/atau baja tulangan) difungsikan sebagai struktur pemikul beban,

- Kesalahan konfigurasi sistem struktur, seperti: tidak mengikuti kaidah struktur bangunan tahan gempa, seperti kaidah: keteraturan, kontinuitas, kesimetrisan pada seluruh bangian bangunan,

- Salah penyelesaian detail tulangan (kasus pada struktur beton),
- Bangunan tradisional joglo, sistem sambungan sunduk, takikan lidah alur, lemah pada sistem sambungan antar batang komponen, mudah patah dan roboh total,

- Bangunan ES (bangunan bertingkat yang dirancang oleh ahli bangunan), mengalami rusak atau roboh total, akibat tidak mengikuti ketentuan SNI bangunan tahan gempa, kesalahannya antara lain sebagai berikut:

- soft story, struktur di tingkat terbawah lemah,

- short column effect and column shear failure, rusak geser akibat kurangnya sengkang penahan geser,

- strong beam weak column and weak joints, kolom terlalu langsing, sementara baloknya terlalu kuat,

- salah detail tulangan (rebar), tidak mengikuti ketentuan SNI,

- kurangnya sengkang penahan geser dan sengkang pengekang di inti join

\subsection{SNI yang Terkait dengan Bangunan Tahan Gempa}

- Tata Cara Ketahahan Gempa untuk Bangunan Gedung", SNI-1726-2002.

- Naskah Final RSNI: "Tata Cara Perencanaan Struktur Beton Untuk Bangunan Gedung".

- Tata Cara Perencanaan Dinding Struktural Pasangan Blok Beton Berongga Bertulang Untuk Bangunan Rumah dan Gedung, SNI03-3430-1994.

\subsection{Kendala yang sering dihadapi}

Kendala yang dihadapi dalam upaya penyebarluasan SNI, antara lain:

- tidak tersedianya dan sulit didapatkannya buku-buku SNI dalam jumlah yang cukup di daerah-daerah,

- belum meluasnya upaya penyebarluasan SNI di daerah-daerah, terutama di luar Jawa.

- terbatasnya tenaga penyuluh terampil (ahli) yang dapat diterjunkan ke daerah-daerah,

- terbatasnya dana yang mendukung kegiatan penyebarluasan SNI. 
5.4 Penyebab tidak teraplikasikannya SNI dalam bangunan

- Bangunan gedung dan rumah dibuat sebelum SNI dilahirkan,

- Sosialisasi SNI belum sampai atau tidak menjangkau ke daerah-daerah tertentu.

- Sosialisasi SNI sudah sampai tetapi pengguna sengaja tidak mau menggunakan,

- keterbatasan ekonomi (tidak tersedia biaya konstruksi yang memadai).

\subsection{Sasaran Penyebar-Iuasan SNI.}

- Perguruan Tinggi Teknik (Jurusan Sipil dan Arsitektur),

- Para konsultan dan kontraktor bangunan gedung dan rumah,

- Para anggota Asosiasi profesional, seperti HAKI

- Para pejabat PU daerah, khusunya pengawas dan pemberi ijin bangunan.

\section{DAFTAR PUSTAKA}

1. Badan Litbang Kimpraswil, Puslitbang Permukiman, 2002. Tata Cara Ketahahan Gempa Untuk Bangunan Gedung, SNI-17262002.

2. Badan Litbang Kimpraswil, Puslitbang Permukiman, 2002. Naskah Final RSNI, Tata Cara Perencanaan Struktur Beton Untuk Bangunan Gedung.

3. S. Suwandojo, 1999. Uji Eksperimental dan Desain Struktur bangunan Rendah Sebagai Alrternatif Perbaikan Struktur BangunanPenduduk di Daerah Gempa, Pusat Studi Masalah Kegempaan, Jurusan Teknik SIPIL ITB, ISBN no. 979-95846-0-4.

4. S. Suwando, 1996. Struktur Bangunan Rumah Tinggal di Daerah Rawan Tsunami, Lokakarya Pengenalan dan Mitigasi Akibat Gempa Tektonik dan Tsunami, 21-22 Mei1996.

5. S. Suwandojo, 1995. Laporan Penelitian dan Evaluasi Lapangan terhadap Kerusakan bangunan Akibat Gempa Hyogo Ken Hanshin KOBE, Japan, 17-1-1995, Laporan Teknis Intern Puskim, Balitbang PU, Dep PU.

6. S Suwandojo. 1987, Earthquake Disaster and Building Structural Damages in Indonesia, Proceeding and Final Report on the Seminar on Technology for Disaster Prevention, Vol 11, Dec 1987, Tsukuba Japan.
7. S. Suwandojo. 1985, Desain Konstruksi Bangunan Sekolah Tahan Gempa, 1985, Jurnal Penelitian Permukiman Vol.1 No. 1 1985.

8. Karlsen G G, 1961, Wooden Structures, UDC 624.011.1/6(0.75.8)=20.

9. German Gurfinkel, 1981, "Wood Engineering", second eddition, Kendall/Hunt Publishing Company, Dubuque, lowa.

10. Keith F. Faherty, Thomas G Williamson, 1989 Wood Engineering and Construction Handbook, McGrraw Hill Publishing Company, USA.

11. American Concrete Institute, 1995. Building Code Requirements for Reinforced Concrete, ACl 318-1995 and Commentary".

12. Boen T, Desember 1992, Manual Perbaikan Bangunan Sederhana yang Rusak Akibat Gempa Bumi,

13. Boen T, Januari 1994. Anjuran Perbaikan Detail Struktur Bangunan Sederhana yang Rusak Akibat Gempa Bumi, Kasus Gempa Halmahera 21-1-1994.

14. Boen T, Februari 1994. Manual Perbaikan Bangunan yang Rusak Akibat Gempa, Kasus Gempa Liwa, Lampung Barat, 16-2-1994.

15. Boen T, Oktober 1995. Manual Perbaikan dan Perkuatan Bangunan yang Rusak Akibat Gempa Bumi, Kasus Gempa Kerinci 7-101995.

16. Boen T, February 1996. Bencana Gempa Bumi: Fenomena, Akibat dan Perbaikan/Perkuatan Yang Rusak, Kasus Gempa Biak, Irian, 17-2-1996.

17. Boen T, 2001, Impact of Earthquake on School Building in Indonesia, paper presented on UNCRD International Workshop and Symposium Titled", Kobe 2931 Jan2001.

18. Anan S Arya dan tim, Oktober 1986. Guidelines for EQ Resistant Non-Engineered Construction, The International Association for EQ Engineering, Tokyo, Japan.

19. Kepres RI No. 106 Tahun 1999. "Badan Koordinasi Nasional Penanggulangan Bencana, Bakornas

20. Kepres RI No. 3 Tahun 2001, Badan Koordinasi Nasional Penanggulangan Bencana dan Penanganan Pengungsi, Bakornas PBP

21. CIDI, 2000, Indonesia Earthquake 12-June2000. OCHA Situation Report No. 5, $12-$ June-2000, Case: Bengkulu EQ 4-5-6 June 2000. 
22. Nanang T Puspita Gunawan, 2001. National Report of the Republic of Indonesia on Tsunami.

23. Nanang T Puspita, Desember 2002, Sepuluh Tahun Setelah Bencana Tsunami Flores, Kompas Cyber Media, 21-Des-2002.

24. Badan Meteorology dan Geofisika, 2003. Sejarah Tsunami di Indonesia Bagian Timur.

25. George PC, 2002, The Great Tsunami of August 26, 1883, from the Explosion of Krakatau in Indonesia.

26. Nelson Joku, 2000, The Impact of 17-7-1998 Tsunami at Jayapura, Indonesia.

27. Edward Bryant, 2001, Tsunami: Where They Happan and Why.

28. S Suwandojo, 1993, Perilaku Kolom terhadap Beban Kombinasi Aksial Tekan dan Lateral Siklis, Jurnal Penelitian Permukiman IX,11-12, Des 1993, ISSN 0215-0778.

29. S. Suwandojo, 1993, Perilaku Komponen Struktur Bakok Beton Bertulang terhadap Beban kombinasi Geser dan Lentur Siklis, Jurnal Penelitian Puslitbang Permukiman, 1993.

30. S. Suwandojo, 1991, Ketentuan Perencanaan Komponen Struktur Balok Beton Bertulang, Berita Himpunan Ahli Konstruksi Indonesia, Edisi Mei-Juni 1991,

31. S. Suwandojo, 1996, The Behavior and Shear Capacity of Reinforced Concrete
Hollow Block masonry Walls, subjected to combined Axial and Lateral Cyclic Loadings, Proceeding of HAKI Conference on Civil and Structural Engineering, Jakarta 21-22 August 1996, ISBN 979-95080-1-0.

32. S.Suwandojo, 1994, Dinding Pasangan Bertulang Sebagai Komponen Struktur Tahan Tsunami, Prosiding Seminar Sehari, Masalah Tsunami di Indonesia, Bandung, 6September 1994, ITB Bandung.

33. S. Suwandojo, 1996, Struktur bangunan Rumah Tinggal di Daerah Rawan Tsunami, Lokakarya Pengenalan dan Mitigasi Akibat Gempa Tektonik dan Tsunami, Dep PU, PT Bina Karya dan Flores Earthquake Reconstruction Project, Ujung Pandang, 2122 Mei 1996

\section{BIODATA}

Prof. Suwandojo Siddiq, DE Eng, APU, dilahirkan pada tahun 1942. Penulis mendapatkan gelar Research Prof. Bidang Teknologi Gempa untuk Struktur Bangunan Tinggi pada tahun 2005. Penulis adalah Peneliti Utama Bidang Struktur dan Teknologi Gempa. Sejak tahun 1980 sampai sekarang, Penulis bekerja sebagai Peneliti Bidang Struktur \& Teknologi GempaPuslitbang Permukiman, Departemen Pekerjaan Umum. 